\title{
Adatok a németlukafai üveghuta történetéhez
}

\author{
HORVÁTH J. GYULA és EPERJESSY ERNÖ** \\ *H-1149 Budapest, Dongó u.14. \\ E-mail: eperjessy.erno@gmail.hu
}

\begin{abstract}
HoRvÁth, J. Gy. \& EperJessy, E.: Supplementary data for the history of the glasshouse of Németlukafa.

Abstract: In the 18th and 19th century several glasshouses operated in the forests of Zselic region. One of the most significant ones was in operation between 1799 and 1888 in Németlukafa. The equipment of the faience manufacture, which was working side by side with the glasshouse, was bought by the Zsolnay family of Pécs in the 1850's and became the first machine line of their factory. The manuscript of the monograph written on the topic by Gyula J. Horváth has disappeared around the time of his death (2003). The present study attempts to save the valuable notes as were left in his heritage and completes it with knowledge of the author.
\end{abstract}

Keywords: Zselic, Németlukafa, potash, glasshouse, pottery.

\section{A társszerzőség indoklása}

E tanulmány menteni akarja, ami egy sajnálatos helyzetben menthető. Ezen írásnak célja, hogy Horváth J. Gyula (1918-2003) németlukafai üveghutáról ${ }^{1}$ írt monográfiájának elveszett kézirata helyett, a fennmaradt résztanulmány, szócédulák és feljegyzések mozaikjait összerakja és újabb adatokkal kiegészítve - ha töredékeiben is - az utókornak átörökítse.

Horváth J. Gyula 1945 és 1994 között Almamellék, majd az 1980-as években Mozsgó és Ibafa rk. esperes plébánosa is. Az 1950 és 2000 közötti időben egyike a Zselic tájegység elmélyült tudós kutatóinak. 1971 és 1983 között aktív résztvevője a (6) Zselici Konferencia sorozatnak. A régióval kapcsolatban a Zselici Dolgozatok I-V. kötetében több tanulmánya is megjelent. Önálló kötete: Az ibafai papnak fapipája van (1999). Életmüvének az Almamellék határában lévő, németlukafai üveghutával kapcsolatos öt évtizedes kutatását, illetve befejezett monográfiáját tartotta. Információink szerint a többszáz oldalas kéziratot 2002-ben fejezte be, majd lektorálás céljából környezete előtt ismeretlen személyre bízta. ${ }^{2}$ Kiadásra 2003 januárjában történt elhunyta miatt már nem kerülhetett sor. A hagyatékból eltünt kéziratnak másolata nem maradt, az eredeti hollétét kö-

1 Atanulmányban az üveghutával kapcsolatban elöforduló szinonímák, rokon szakkifejezések. Magyar: huta, üveggyár, öveggyár, üvegbánya, övegbánya, üvegcsür, bánya, üvegfuvó, üvegolvasztó, üvegkohó. Német: Glasshütte, Glasswerk, Glasblöserei, Glaswersktatt, Glaserszeigung. Latin: vitrária - üveghuta, vitrárius - üveghutai munkás.

2 Informátor: Szervei Istvánné Miholcsai Mária, Almamellék, 2003. Idős korában több évig Horváth J. Gyula gondozója és hagyatéka egy részének örököse. zel tíz esztendő óta sem sikerült felderíteni. ${ }^{3}$ Örököse a hátramaradt szócédulák, feljegyzések, résztanulmányok egy részét a jelen társszerzőnek adta át felhasználásra. ${ }^{4}$ Ezek összeszerkesztése után, újabb kutatók és a társszerző (Eperjessy Ernő) adataival kiegészítve adjuk közre a tanulmányt abban a reményben, hogy a jövőben Horváth J. Gyula teljes monográfiája egyszer mégis előkerül és a köz javára napvilágot lát.

\section{Hamuzsírfőzők és üveghuták a Zselicben}

A XVIII. század végén és a XIX. században a Zselicben jó egynéhány üveghuta müködéséröl van tudomásunk. Ezek a huták a manufakturáknak abba a csoportjába tartoznak, amelyeket a kutatók „erdei üveghutának”, termékeit „erdei üvegnek” neveznek. Ezek jellegzetessége, hogy müködésük célja nem annyira a kapitalista értelemben vett profitszerzés, hanem a más célra akkor még nem hasznosítható erdők intenzívebb kihasználása volt. A fa, amelyet a török kor utáni őserdők óriási tömegben kínáltak, a földek és erdők birtokosainak nem nagy jövedelmet biztosított. Az erdők fájának értékesítését - még ha esetleg mutatkozott volna is iránta kereslet - a kiépített utak hiánya lehetetlenné tette, a közlekedés és szállítás igen nehézkes és drága. A gyér lakosságú vidék erdői, őserdei állapotok szerint lerogytak és elkorhadtak. ${ }^{5}$

3 A németlukafai üveghutáról készülő monográfiát Baranya megye több neves kutatója, levéltár és múzeum is figyelemmel kísérte, megjelenését várta. Lang Ádám: Üveghuták a Kelet-Mecsekben című könyvében írja (Pécs, 2008.77.): „A németlukafai és más zselici üveghuták történetét évtizedeken át kutatta Horváth J. Gyula, Almamellék tudós plébánosa. Kézirata elhunytát követően hagyatékából eltünt, ami súlyos veszteség a hazai üvegtörténeti kutatás szempontjából... Horváth J. Gyula kéziratát sajnos már én sem tudtam felhasználni munkám során."

4 Szervei Istvánné 2004-ben Horváth J. Gyula hátramaradt feljegyzéseinek egy részét (szócédulák, jegyzetek, adatok, stb.) rendezetlenül további megőrzésre és felhasználásra Eperjessy Ernőnek adta át. Ezek között a lukafai üveghutával kapcsolatos: az eltűnt monográfia 43. oldaltól 62 -ig terjedő géppel írott része indigós másolatban, valamint Horváth J. Gyula 1990-es években Bárdudvarnokon tartott üvegszimpozionra készített előadásának 12 féloldalas, kézzel írott vázlata. A másjellegü (Canonica Visitatiokból, egyházi sematizmusokból, stb. kiírt) feljegyzései Timár György egykori paptársához, egyházkutatóhoz kerültek 2006-ban, aki akkor Kővágószőllős plébánosa volt (Pécsi Egyházmegye).

5 H. J. Gy. Kéziratrészleg: 43.p. - Raichl Sándor adata szerint, (ak 1920-1938 között Szentmárton-puszta és Németlukafa uradalmi intézője): AXVIII. sz. végén a zselici erdőkben egyértelmüen a hamuzsirfözés és az üveggyártás hozott hasznot. Akkor Kaposváron 4 koronáért lehetett eladni egy szekér fát, és 5 koronába került a szállitás. (Gyüjtő: Eperjessy, 1969). 
Amikor telepesek vagy telepesrajok érkeztek, akkor erdőt irtottak, tuskóztak, hogy alkalmas terepet biztosítsanak a földművelésnek. Példának említhetjük: az ibafai telepesek 1745-ben érkeztek Horvátországból. A falu és a szántóföldek helyét erdőirtással tették lakhatóvá és művelhetővé. Kollárovits Sebestyén mozsgói plébános írja, hogy 1793-ban Ibafán még látott hatalmas tuskókat, amelyek az erdőirtásból maradtak. ${ }^{6}$ Elképzelhető a hatalmas munka, ha még 50 év múlva sem sikerült egészen megtisztítani a terepet. A fának értékesebb részét nyilván építéshez és tüzifának használták fel, a kevésbé értékeset pedig elégették.

Ezidőben az erdőirtás kissé nagyobb hasznot adó formája a fahamu égetés, a hamuzsír főzés és a faszén égetés volt. Ugyanis a hamuégetők a kivágott fának nemcsak az értékesebb részeit - hasáb, dorong, ágfa, tuskó - használták fel, hanem hamunyerés és hamuzsírfőzés céljára a gallyakat (rőzsét) és a száraz lombot is elégették. A Pécsi Püspöki Levéltárban található egy 1766-ból való egyházmegyei lélekszám-összeírás, amelyhez küldött jelentésében a mozsgói plébános a plébániához tartozó falvak adatai után külön felsorolja a falun kívül élő (vizes-) molnárokat és hamuzsírfőzőket. Ebbe a sorba veszi a hamuégetőket is. A „His accedunt Molitores et Accsungistore per diversa loca disperti" részben olvasható: - Szentlászlón túl fekvő Bikinben lakik a Festetics uradalom hamuégetője. Azután: „Post Boldogasszonyfa in Monte cingarórum - (Boldogasszonyfán túl, a Cigányhegyen) - hamuzsírfőzők laknak.” Még egy adat számunkra: „In Puszta Lukafa, post Hertelend: accsungister Joannes Pruk cum Margaritha. - Hertelend után Lukafapusztán lakik Pruk János, (feleségével) Margittal, akik hamuzsírfözők" 7

Orbán György somogyhárságyi plébános, aki 1857ben írta a plébánia történetét, feltünteti a plébánia lakott helyeit: „Ezen plébániához tartozik Nagy és Kis Hárságy, Magyar Lukafa és Viszló helységek és a Vitorági puszta." Ugyanott Vitorág pusztáról, - amely akkor külterületi hely Magyarlukafa határában, - a következőképpen beszél: „Az idetartozó Vitorág pusztán hamuzsirfőzés volt, melly 1846-ban megszünvén ugy szólva egészen néptelen." 8

Itt említjük meg, hogy más zselici erdörészekben és falvak múvelés alatti mezeiben Hamuháza, Hamuházi-mező, Hamuházi-dülö, Hamuházi-földek, Hamuházi-rét, Hamusgödör, Hamusdomb, stb. (még Pepelka, Pepelárnica - horvát: hamuégető hely formában is) dülőnevek örzik e régi mesterség emlékét. ${ }^{9}$ Mozsgó közigazgatási határában lévő Elekmajor pusztát a XX. sz. végén is régi nevén, Kalamázvölgyként ismeri a nép-

6 Sajnos a feltalált kéziratokban Horváth J. Gy. a forrás pontos vonatkozásait nem jelöli.

7 H. J.Gy. Kéziratrészleg: 43-44. p. (Eperjessy Ernő birtokában, 2012)

8 Vitorág a XIX.sz. végén uradalom (puszta), 1945 után állami gazdaság. Az 1990-es években elnéptelenedett.

9 Somogy vármegye földrajzi nevei Szerk.:Várkonyi Imre, Király Lajos. Akadémiai Kiadó, Bp.1974. 946. p.; Király Lajos: Ipartörténeti emlékek Somogy megye földrajzi neveiben. In: Kutatások a gazdasági és társadalmi élet szolgálatában. Dél-Dunántúli Konferencia - Szekszárd. 1975. Megjelent: Szekszárd,1976. 156-163. p. nyelv. ${ }^{10}$ Ugyanis az ipari hasznosításra (szappanfőzés, üveggyártás, papír- és lőporgyártás stb. célra) készült hamuzsír népies neve szlávos változatában: kalamász. Ez utóbbi a délszláv kolomaz - azaz kocsikenőcs szóból ered, mivel a korábbi századokban a hamuzsírt kocsikenőcsként, keréktengelyek síkosítására is használták. A hamuzsír magyar elnevezése Dunántúlon általában degec, az Északi-Hegyvidéken szalajka, a hamuzsírfözőké pedig (valószínúen rideg életkörülményeik miatt) a Zselicben: hamusbetyár. Németül: aschenbrenner, horvátul pepelar, pepelari. ${ }^{11}$ Ugyanis nemzetiségük szerint többnyire németek és „tótok”, ez utóbbi az akkori értelmezés szerint nemcsak szlovákot, hanem horvátot és szlovént is jelentett.

A XVIII-XIX. század során a Mecsekben és a Zselicben az erdőknek komplexebb hasznosítására - mintegy másodfokon - az üvegkészítés jelent meg, amelyhez ugyancsak az erdők szolgáltatták egyik legfontosabb nyersanyagot. A hamuból hamuzsír készült, ami tulajdonképpen káliumszóda (káliumkarbonát $-\mathrm{K}_{2} \mathrm{CO}_{3}$ ), az üvegkészítés egyik legfontosabb alapanyaga. Egyrészt a fa elégetése szolgáltatta a nagy hőigényű üzemhez a szükséges energiát, az üstök alatt visszamaradó hamuból pedig újra hamuzsír készült, így az üzem önmagát táplálta nyersanyaggal. ${ }^{12}$ Természetesen a kohókban eltüzelt fahasábok hamuja nem volt elegendő, továbbra is szükség volt e célra termelő hamuégetők és hamuzsírfőzők munkájára. Ezért a huták környékén a hamuégetők és a hamuzsírfőzők nem fogytak, hanem szaporodtak. ${ }^{13}$

Annál is inkább, mert a hamuzsír (ikrás libazsírra emlékeztető áttetsző anyag, ezt később igény szerint e célra készített kemencékben, kristályos por állapotig tepsikben hevítették tovább), az üveggyártás mellett, mint több más fontos iparág nyersanyaga, piacon is egyre keresetebb cikk. llyenképpen, hogy a hamuzsírégetés, majd az üveggyártás megjelenése a megközelíthetetlen őserdők mélyén, az ott lakóknak a túlélést biztosította, a földesuraknak némi többlet hasznot is hozott. Ezeken túl a földet birtokló nemességnek azért is jól jött az üveggyártás, mert ez a hatalmas erdőfaló mesterség mind több irtásföldet szabadított fel a földművelés számára, a szántóföld pedig a korabeli perspektívák szerint a lehető legnagyobb hasznot jelentette.

Ugyanakkor a jobbágyszolgáltatásokon alapuló nemesi nagybirtok rendszeren a Mecsek és a Zselic térségében éppen ezek a kis erdei manufaktúrák ütötték az első rést. Ugyanis a hamuzsírfőzés, faszénégetés, majd az üveggyártás a szokványos jobbágymunka rendszerében megbukott, teljesen ráfizetésesnek bizonyult. Ezt még a pécsi egyházmegye kiváló kormányzati egyéniségének, Bohus kanonoknak is be kellett látnia,

10 Adatközlö: Németh Györgyné Pamuki Ágnes, 79 é. 2003. Almáskeresztúr (Elekmajor); Vusics Jánosné Hamarics Julianna, 88 é. Almamellék, 1997.

11 Horvát nyelvi konzulens: Frankovics György

121 q hamuzsír előállítására 40-50 q fahamura, illetve 60-70 köbméter tömör bükk és tölgyfa elégetésére volt szükség. In: Lehmann Antal: Adatok a szentlukai üveghutáról (1807-1808). Somogy megye múltjából. Szerk.: Kanyar József. Kaposvár, 1971. - A hamuzsír készítésének módja: $A$ fahamut hatalmas fakádakban vízben áztatták.. Több nap után a lúgos vizet leszürték, nagy üstökben addig forralták, amig libazsír sürüségü anyagot, hamuzsírt kaptak.

13 H. J.Gy.Kéziratrészleg: 44.p. 
aki pedig a hamuzsírfőzők és üvegcsürök termelésének rendszerét a jobbágyszolgáltatások részeként dolgozta ki és szervezte meg. ${ }^{14}$ Miután e tevékenységek ebben a formában teljesen ráfizetésesek voltak, az üveg és alapanyagainak gyártását már vállalkozókra kellett bízni. (Későbben ezt az utat választotta a pécsi püspökség Hosszúhetény, Pusztabánya, Óbánya-Alte Glashütte, Újbánya-Neuglashütte, stb. esetében is.) Az itt embertelen körülmények közt dolgozó munkások már nem jobbágyi függésben termelnek, hanem igazi ipari vállalkozóknak tekinthetők. ${ }^{15}$

Ebbe az új, kezdetleges ipari rendszerbe kapcsolódnak be a zsidók, akik sok évszázados kereskedelmi gyakorlatukkal fontos szerepet töltenek be az üveggyártás és értékesítés folyamatában. Koordinálják a hamuégetők és a hamuzsírfőzők munkáját, gondoskodnak a kész áru raktározásáról, elszállításáról, az üvegkészítők kész termékeinek (öblösüveg, táblaüveg) közvetítéséröl és eladásáról a monarchia más részeiben. Kereskedelmi úton ők lesznek szállítói a helyben nem található alapanyagoknak (kvarchomok, mész, kaolin, stb.), bizonyos munkaeszközök, mindennapi használati cikkek (főzőüstök, szerszámok, lábbelik, textíliák, világítóeszközök, stb.) beszerzői. Nem utolsó sorban öszszeköttetéseik révén tőkét szereznek új főzőcsűrök és üvegfuvók létesítéséhez. ${ }^{16}$

A zsidóság szerepének emlékét őrzi Németlukafa és az almamelléki vasútállomás közötti, 3-4 km hoszszú erdei kocsiút, amelynek neve napjainkban is Zsidóút. Szekereken erre szállították a lukafai üveggyár és keménycserépgyár termékeinek egy részét. ${ }^{17}$ Ugyancsak tevékenységükre utal a lukafai Zsidóvágás nevü erdőrész, melynek fáját „lábon vették meg”, és termeltették le hamuzsír gyártás céljára. ${ }^{18}$

Habár Zselic üveghutáinak átfogó tanulmányozása még nem történt meg, az utóbbi időben megjelenő helytörténeti kutatások egyre több huta-helyröl adnak hírt. Ugyanis az erdei üveghuták időleges tevékenységet fejtettek ki. Müködésük a kivágható és elégethető erdőktől függően általában 20-30, esetleg 40 évig tartott. Ezután a primitív üzem máshova költözött. Horváth J. Gyula az 1960-70-es években végzett behatóbb kutatásai alapján 1981-ben még arról ír, hogy a XVIII. és a XIX. századból bizonyossággal és dokumentálhatóan a Zselicben 6 „erdei üveghuta” létezését fogadhatjuk el. Megállapításai szerint ezek: 1. Gödre melletti Szentmárton (ma Gödreszentmárton); 2. Somogyhárságyhoz tartozó Magyarlukafa; 3. Gálosfa melletti Szentluka-puszta; 4. Németlukafa (Almamellék legtávolibb határrészében) 5 . Rákó-puszta, régi nevén Hugomér (ma Kaposkeresztúrhoz tartozik); 6. Kétújfalu melletti Szentmihályfa (a Zselic délnyugati peremén). ${ }^{19}$

14 H. J. Gy. Kézírásos vázlat (Eperjessy Ernő birtokában, 2012.)

15 H. J. Gy. Kézírásos vázlat

16 Tartalmi idézet a zsidóság szerepéről , Horváth J. Gyula Bárdudvarnoki üvegszimpozionon tartott elöadásából.

17 Lehmann Antal: XIX. századi üveghuták a Zselicben. Baranyai Müvelődés, 1969. június. Pécs. 95. p.; Adatközlők: Boder (Bodor) József erdész Németlukafa- Almamellék.1950. ; Fodor János SasrétAlmamellék;

18 Adatközlők: Boder (Bodor) József erdész 1950, Németlukafa Almamellék; Raichl Sándor Szentmárton-puszta - Almamellék, 1969.

19 H. J.Gy. Kézirásos vázlat
Horváth (1981-ben írt) jegyzetében szereplő 6 üveghuta biztos létezését, az időközben előkerült újabb adatok módosításaival is elfogadhatjuk. A felsorolásban Horváth J. Gyula „két első, ősi hutának” a (gödre-) szentmártonit és a hárságyit jelöli meg. Második korszaknak, egyben a zselici huták virágkorának a szentlukai és a lukafai hutákat tartja. Harmadik (hanyatló) korszakra a Zselic szélén a szentmihályfai és a rákó-pusztai, vagyis a hugoméri üvegmühelyeket teszi. $E$ két utóbbit már létesítésük idején is anakronizmusnak tartja: „hiszen a mindjobban megcsappanó, erdőpusztító huták kora már lejárt... Ezért a két huta alig két évtizedig vegetált, majd végleg abbahagyta erdőfaló ipari tevékenységét." 20

„Az egyik legrégebbi zselici hutának a (gödre-) szentmártoni tekinthetô" - írja Horváth. - Erről két adatunk is van. Az első 1784-ben készült II. József korabeli katonai térkép, amely Gödre közelében Glashütte névvel jelez egy helyet. A jelzés fölött egy más kéztöl származó Nichtgangbar, vagyis járhatatlan beírás található. Ez a térkép katonai célzattal készült, tehát a bejegyzés is katonai szempontból tartja fontosnak megjegyezni, hogy itt komolyabb katonai egységgel felvonulni nem lehet. ${ }^{21} \mathrm{~A}$ második adat a Winkler Mihály ${ }^{22}$ által írt gödrei plébánia történetében található, ahol Szentmártonról azt olvashatjuk: „...1790-ben itt egy „Glasblöserei”-t, azaz üveghutát létesítettek. Ám ez helytelen adat, mivel láttuk, hogy az 1784-es József császár korabeli katonai térképen már megtalálható, megjelölve, hogy arrafelé az út járhatatlan". - állapítja meg és zárja le ezt a kérdést Horváth J. Gyula, az 1990-es évek elejéről fennmaradt kéziratos előadásában. ${ }^{23}$

Lang Ádám, az üveghuták másik neves kutatója Üveghuták a Kelet-Mecsekben, 2008-ban megjelent kötetében, feltehetően ugyanerről a hutáról, de a földrajzi bizonytalanság miatt más megnevezéssel, már sokkal bővebben tudósít: „...a Bakócához tartozó Kövesdpusztán a Melczer-uradalomban az 1770-es évek elsó felében, de mindenképpen 1771 után létesült üveghuta... Pécs város peres iratainak anyagából is kiderül, hogy 1774-ben már létezett Bakoczai Bánnya. 1781ben készített, szükszavú vármegyei jelentés csupán az üvegcsür létezéséről tudósít. Két évvel később már nagyon elhanyagolt állapotban lehetett a mühely, hiszen a Il. József-féle katonai felmérés országleírásában „Glashütte” helynév alatt ezt olvashatjuk: „egy bedőlt üveghutából és néhány rossz házból áll." A felmérés térképszelvényén a „Glas Hütte a Bakóczáról Szágyra vezető út mentén, a Kövesdi-völgy torkolatában, a Szágyi-patak közelében található,... a hely közel esik Alsókövesd-pusztához, bár nem azonos vele... A huta tulajdonképpen közelebb feküdt Szágyhoz, mint Bakóczához, innen ered a tévedés, hogy Szágyon is lett volna üveghuta. A kövesdi hutát a jozefiniánus fel-

20 H. J.Gy. Kézirásos vázlat

21 Feltehetően ugyanarról a Munnichsmeyer tüzértiszt által 1784-ben készített térképröl van szó, amelyre későbben Lang Ádám is hivatkozik.

22 Winkler Mihály kétízben is volt Gödrén plébános: 1757-1759 között és 1789-töl 1810-ig, haláláig. A második szakaszban a tehetséges és alkotó egyéniség a plébánia történetét latin és német (1790), a zsidóknak szánt művét és a velük folytatott levelezését héberül írta.

23 H.J.Gy. Kézírásos vázlat 
mérést követően renolválhatták, hiszen egy 1785-ben készült, újabb kimutatásban már ismét szerepelnek az üvegcsür termelési adatai." - írja Lang Ádám. ${ }^{24}$ Ugyancsak ő tudósít arról, hogy az előkerült termelési adatok szerint a bakócai üvegbánya a korabeli Magyarország jelentősebb hutái közé tartozott. A fennmaradt dokumentumok alapján ismerteti az egy időben felhasznált nyersanyag adatait, $s$ többek közt azt is, hogy a mester irányítása alatt 15 fő dolgozott, köztük 8 osztrák származású segéd, stb. Egy későbbi, 1817-es térképen ismét régóta elhagyott helyként jelölik. ${ }^{25} \mathrm{~A}$ birtokhatárok és a korabeli térképjelölések bizonytalan adatai, valamint a köztes földrajzi fekvése miatt ugyanez a huta, amely Bakóca közigazgatási területén, Felsőkövesdhez és Alsókövesdhez egyaránt közeli, ma is Bánnya erdörésznek nevezett helyen müködött. ${ }^{26}$ Különböző időben és különböző szerzők szentmártoni, szágyi, kövesdi és bakóczai „Glashütte” néven is emlegetik. Nem kétséges, hogy az 1784-es katonai térképen jelölt hutát - Lang Ádám és Lehmann Antal későbbi feltárásai alapján a Horváth J. Gyula által „szentmártoninak” vélt hutával azonosnak kell tekintenünk.

Mint láttuk Horváth J. Gyula, Winkler gödrei plébános feljegyzéseire hagyatkozva, mindvégig bizonytalan volt e kérdésben. Ugyanis Winkler az 1799 körüli feljegyzésében e régióban, egyazon időben 3 üveghutát is emleget. Gödreszentmártonról azt mondja: „...1790-ben itt egy üveghutát (Glasblöserei) létesítettek". Lukafáról pedig azt olvashatjuk: „1799 jan. 21-én a lukafai üveghutában (Glaswerkstatt) is megkezdték a munkát...", majd e sorok után közvetlenül írja: „Ezzel (vagyis a lukafai üveghuta beindításával) vidékünkön három üvegelöállitó üzem (drei Werkstatten für Glaserszeugung) müködik... Szentmártonban, Szentlukán és most Lukafán." - idézi Winklert Horváth J. Gyula. ${ }^{27}$ Ezekből kettő (Szentluka és Lukafa) létezését biztosan tudjuk. Ugyanakkor továbbra is nyitottnak látszik a szentmártoni huta létezésének kérdése. Ugyanis a helyi ismeretekkel rendelkező Winkler plébános (Horváth jegyzetei szerint is) az 1784-es térképen szereplő és elhagyottnak jelölt hutáról semmit sem tud, nem is említi, hanem (Gödre-) Szentmártonról írja: „...1790-ben itt egy üveghutát (Glasblöserei) létesítettek... 1799. január 21-én a lukafai üveghutában is megkezdték a munkát, ...Ezzel vidékünkön három üzemben folyik üvegelőállítás (drei Werkstatten für Glaserzeugung): Szentmártonban, Szentlukán, amely Bozsa plébániához tartozik (Winkler így nevezi Bőszénfát) ez egy évvel ezelött kezdett müködni, most pedig legutóbb Lukafán." ${ }^{28}$ Ezek alapján az is feltételezhető, hogy a bakóczainak tudott Bánnya hutától függetlenül, rövid ideig valóban (Gödre-) Szentmártonban is müködött üvegkészítő mühely. Lehmann Antal A XIX. századi üveghuták a Zselicben c. tanulmányában érintőleg szintén említi a Petrovszkyak

24 Lang Ádám: Üveghuták a Kelet-Mecsekben. 2008. Pécs. 75-76. p. 25 Lang Á .ua. 76. p.

26 A hajdani üvegbánya helye Felsőkövesdhez közeli erdőrészben ma is „Bánnya” néven ismeretes. Adatközlő: Hauser Mátyásné Frigyesi llona, Ibafa, 2012

27 Winkler Mihály gödrei plébániáról írt története alapján 1790)

28 Ugyancsak Winkler gödrei plébánia története alapján szentmártoni birtokán lévő hutát. ${ }^{29}$ Mérey Gyula is utal a baranyai Szentmártonban 1794-1798 között müködő hutára. ${ }^{30}$ Ezen kívül a természettudós Kitaibel Pál 1799-ben Baranya megyei útja alkalmával naplójában írt feljegyzése is ezt látszik megerősíteni, amely szerint: „Gödreszentmártonban üveghuta van. Az üveggyártáshoz szükséges homokot Szentkatalin és Kán között ássák. Hamuzsirt az üveghuták főznek." ${ }^{31}$ Ha későbbi kutatások meggyőzőbben dokumentálnák, a Zselicben ez a hetedik egykori üvegcsür (Glasblöserei) lenne.

Horváth a somogyhárságyi hutával kapcsolatban Orbán György helyi plébános 1854-ben közölt adatából indult ki. Ő a keresztelések számából következtetve állítja: „Ezen plébánia közelében, nevezetesen Kis Hárságytól északnyugatra egy kellemes völgyben, melly ma is Glas Hütte nevet visel, hajdan üvegbánya volt..., mellynek azonban az anyakönyvekben 1799 után nincsen nyoma." ${ }^{32}$ A bizonytalan földrajzi megjelölés alapján Horváth J. Gyula akként vélekedik: „Ha valóban így van, ahogyan Orbán plébános ezt tudja, akkor annak helyét a leírás alapján Magyarlukafa területére tudjuk lokalizálni ..." ${ }^{33} \mathrm{Az}$ adat azonban anynyira bizonytalan, hogy az 1982-ben megjelent Baranya megye helynevei címü kiadvány szerkesztője is csak Pesty kutatásaira hivatkozva meri állítani, hogy ilyen volt. (Mivel Horváth J. Gyula Somogyhárságyon és környékén az 1970-es években végzett helyi kutatásai során olyan élő adatszolgáltatót nem talált, aki Hárságy határában lévő hutáról valaha egyáltalán hallott volna, egykori létezését is kétségbe vonta. Többek közt az 1990-es években Bárdudvarnokon tartott üvegszimpozionon elhangzott előadásában.) ${ }^{34}$ Horváth említett álláspontja óta azonban számos újabb adat került elö, amely szintén a somogyhárságyi „Glashütte” valóságos létezése mellett szól. Lang Ádám Üveghuták a Kelet-Mecsekben c. könyvében már részletes adatokat közöl Somogyhárságyhoz tartozó Festetics-uradalom birtokában lévő „üvegbánya” termeléséről, a nyersanyag források eredetétől egészen az értékesítést végző ismert kereskedelmi célpontokig. ${ }^{35}$ Ugyanakkor ő is megjegyzi azt a zavaró körülményt, hogy eleddig egyetlen katonai térkép vagy térképszelvény sem tünteti fel helyét. ${ }^{36}$ Ezt a kérdést látszik tisztázni az alábbi empirikus adat: 2001-ben Kishárságytól keletre, mindössze 2-3 km-re lévő Kisszentlászlópusztán az akkori tulajdonos, Tanács Béla juhász a Kisszentlászlói-patak mentén északra, Margitta-puszta irányában a birkák által kitaposott temérdek üvegcserépre hívta fel a társszerző figyelmét. ${ }^{37}$ Tekintve, hogy

29 Lehmann Antal: XIX. századi üveghuták a Zselicben. ua. 94.p.

30 Mérey Gyula: Magyar iparfejlödés 1790-1848. Bp.1951.

31 Lehmann A. ua. II8. p.

32 Orbán György somogyhárságyi plébános dokumentumainak fellelhetőségére Horváth J. Gyula hagyatékában nem maradt utalás.

33 H. J. Gy. Kézírásos vázlat

34 H. J. Gy. Kézírásos vázla

35 Lang Ádám: Üveghuták története a Kelet-Mecsekben. 2008. Pécs. 76 -77. p.

36 Lang, ua.77.p.

37 Kisszentlászló-puszta birtokosa, Tanács Béla juhász közlése: „Tessék már mondani, mitöl van arra Margita felé a legelön olyan sok üvegcserép? A birka mind kijárja, a lábát meg fölsérti." - mondta. Gyűjtő: Eperjessy Ernő, 2001. 
ez a völgy a XIX. században Festetics-birtokrész volt és a somogyhárságyi plébániához tartozott, bizonyossággal itt lehetett az Orbán által említett - s közben elfelejtett - „Glashütte” valós létezésének helye. Orbán csupán annyiban tévedett, hogy a „kellemes” völgy nem a vízválasztó Kishárságytól északnyugatra, azaz Magyarlukafa irányában, hanem a másik oldalon, északkeletre keresendő. (Ilyenképpen Horváth rábólintása Magyarlukafára is téves. Magyarlukafán üveghuta nem volt.) A magyarlukafai feltételezés a szakirodalomban később is számos félreértésre adott okot. Ugyanis ebben a zselici térségben innét mintegy 18-20 km távolságra egy másik Lukafán, pontosabban Németlukafán (Almamellék határában) minden kétséget kizáróan jelentős üveghuta és keménycserép manufaktúra létezett. Termékeinek egy része „Lukafai üveggyár" jelzéssel került kereskedelmi forgalomba. A helyi ismeretekkel nem rendelkező szakirodalomban a két (Magyar- és Német-) Lukafa neve napjainkig is gyakran kontaminálódik egymással. 1949-ig mindkét Lukafa még Somogy vármegyéhez tartozott, a könynyebb különböztethetőség miatt a Somogyhárságy melletti Lukafa Magyar-, a németnyelvü lakossággal és üveghutával rendelkező település pedig a Németnévtoldalékot kapta.

Szentluka külterületi lakott hely Gálosfa határának déli részén, alig néhány kilométerre Németlukafától (lakóinak száma 1973-ban 41, 2000-ben lakatlan). Nevének tanúsága szerint a középkorban Szent Lukács tiszteletére szentelt termploma és plébániája volt. A múlt (XIX.) század elején itt üveghuta vagy ahogy akkor nevezték, „öveg-bánya” működött, amely Bozsa (Bőszénfa) plébániához tartozott. ${ }^{38}$ Winkler feltételezéseiből Horváth J. Gyula arra következtet, hogy a szentlukai „Glasblöserei” 1798-ban kezdi termelését és 1826-ban szünt meg. A Festetitsek gálosfai uradalmához tartozó huta fennmaradt „Számodás”-ából tudjuk, hogy a 43 munkást foglalkoztató, közepes kapacitásúnak tekinthető üvegfúvó, 1807-1808-ban még bizonyosan működött. Behatóbb kutatásával Lehmann Antal fogalkozott. ${ }^{39}$

A ma Kaposkeresztúrhoz (más szerzők szerint Kaposhomokhoz) tartozó Rákó-pusztával - régebbi nevén hugoméri-erdei üveghutával kapcsolatban Horváth jegyzeteiben a következők olvashatók: „Az egyik legkésőbben keletkezett zselici huták egyike a hugoméri. Egy adat szerint 1827 előtt kezdte el müködését és 1851 elött fejezte be." 40

„A Kétújfalu melletti szentmihályfai huta keletkezésére és megszünésére már többszáz anyakönyvi kijegyzésem van. 1830-ban már lakik Szentmihályfán vitrárius (latin: üvegkészítő). Ez lehet a huta kezdő éve is. 1831-1833-ban újabb „öveges legény” bejegyzést találunk. ... Az ibafai feljegyzések azt tanusítják, hogy Czindery László az iparpártoló földbirtokos alapításával az üveghuta 1841-ben kezdi meg termelését. Sok más későbbi bejegyzés azt látszik bizonyítani, hogy ez az

38 H. J.Gy: Kéziratrészleg, 46.p.;

39 Lehmann Antal: Adatok a szentlukai üveghutáról (1807-1808). Somogy megye múltjából 2. Kaposvár, 1971. 109 -136. p.

40 H. J.Gy. Kézírásos vázlat üveghuta 1856-ban fejezte be müködését." - írja Horváth, Bárdudvarnokon elhangzott előadásának jegyzetében. ${ }^{41}$

A Zselicben müködő üveghuták közül különös jelentőségre éppen (Német-)Lukafa tett szert, amely Dunántúl legtovább müködő „erdei üveghutája” volt. Termelésének kezdetét - Winkler gödrei plébános feljegyzésének jóvoltából - naprakészen ismerjük: 1799. január 21, majd közel 100 éves müködés után - bizonyossággal mondhatjuk - „végleg 1888-ban húnytak ki kemencéinek lángjai." 42

\section{(Német)Lukafa története a török kiűzéséig}

Lukafa névadója Szent Lukács evangélista, szlávos változatában: Luka. A térségben a középkorban 3 helységet is jelöltek Szent Lukács tiszteletére: Németlukafa, Magyarlukafa, Szentluka. A két Lukafalva azt is jelentette, hogy első birtokosuk neve Lukács volt. Horváth J. Gyula meg nem jelölt forrásadatai szerint, Lukafa (Lukafalva) a török elött is lakott hely volt. 1542-ben köznemes és egytelkes nemesek birtoka. A köznemes Csorbai Miklós özvegye egy portányi birtokkal rendelkezik a faluban. 8 egytelkes is birtokol itt, akiknek törvényben megállapított hatvanadot kell fizetni. Kokoth György 7 dénárt, Pethe György 8 dénárt, Egri Orbán 11 dénárt, Rajky Péter 8 dénárt, Hegedüs Barnabás 3 dénárt, Érsek Ambrus 27 dénárt és Pintér Bálint 40 dénárt kötelesek befizetni hatvanad címén. Az összeíró megjegyzi, hogy Pethe János „szegény”, mentes a fizetés alól. (Nevek alapján a lakosság ekkor magyar.) Megjegyzendő, hogy a falu az egytelkes baranyai falvak között nagyon szegény. Ha a Baranya megyében található 63 falut, amelyben egytelkes nemesek élnek, vagyoni álapotuk szerint rangsorba állítjuk, Lukafalva az 57 . helyet foglalja el, azaz szegényebb csupán 6 van, ezek is Lukafalvának közvetlen közelében.

A török megjelenése után Lukafalván 1554-ben 2 adózó van: Peti Petre és Tenyerös Ferenc. 1565-ben 4 adózót talál a defterdár (török adószedő), 1571-ben hatot: Nagy Benedik, Katat Antal, Katat Tomás, Kis Petre, Erszék Máti és Antal István.

A török idők alatt a falu valószínűen teljesen elnéptelenedett, majd sok más élő, vagy kipusztult faluval és határával együtt a török után a Batthyány-család birtokába kerül. Az egykori Lukafalva közelében - II. József korában - e hatalmas területen számos régi falucska helyén egyetlen község, Almamellék alakult újjá. Külterületén több középkori lakott helyen (Lukafa, Sasrét (Sásrét), Terecseny, Szentmárton, Szentegyed, Korcsány) uradalmak keletkeztek, vagy csak dűlőnevekben (Aligvár, Ördöglik, Kisterecseny, Végág, Vörösföld, Karán) maradt fenn emlékük. ${ }^{43}$

41 H. J. Gy. Kéziratrészleg, 46.p.

42 H.J.Gy. Kéziratos vázlat és Kéziratrészleg, 60. p.

43 Németlukafa középkori történeti adatai, $H$. J. Gy.-tól, forrás megjelölése nélkül. Kéziratrészleg, 48-49. p. 


\section{Adatok a lukafai üveghuta és cserépedény üzem működéséről (XVIII-XIX. század)}

Lukafa a XVIII. század végén megint lakott hely lesz. Egy 1780-as és a már említett József császár korabeli (Munichsmeyer tüzértiszt által készített) 1784es térkép is feltűntet néhány házat Lukafa néven. ${ }^{44}$ A XIX-XX. században megrajzolt térképszelvények pedig már rendre jelölik (Német-) Lukafa helyét. Az első gyér adatok szerint - amikor csak néhány család lakja - Lukafa, miként Terecsenypuszta is - a mozsgói plébániához tartozott. (Erröl tanúskodik az 1766. évi adat, amely megemlékezik Pruk János hamuzsírfőzőről.) A továbbiakban Almamellék község északi része a gödrekeresztúri ${ }^{45}$ plébánia filiálisa. (Winkler plébános ezért tudja naprakészen 1799-ben a lukafai Glashütte termelésének kezdetét.) Az ibafai plébános 1821-ben a kereszteltek anyakönyve évkezdő adatai közt bejegyzi, hogy Lukafát a gödrekeresztúri plébániától elszakították, s mint filiálist lbafához csatolták. Az ibafai plébánia levéltárában ettől az időponttól találunk értékes adatokat a lukafai vitráriusokról. (Lukafát 1957-ben csatolták az almamelléki lelkészséghez. ${ }^{46}$ )

A gödrekeresztúri plébánia anyakönyveit 1745-ben kezdték vezetni, s elég korán megjelennek a lukafai lakosok. Kár, hogy ebben az időben nem jelölik a foglalkozást, így az üveges mesterségre sem tudunk következtetni. Az első német nevű egyén bejegyzése 1766-ban, majd 1769-ben jelenik meg. 1771 után valamilyen oknál fogva folyamatosan gyarapodik a lukafai lakosság száma. 1771-ben 5, 1772-ben 3 keresztelést jegyeznek be Lukafáról és ezentúl 1796-ig is rendszeres a néhány keresztelés. Feltehetően ezek hamuégetők, hamuzsírfőzők (Cinerarii et accsungiatores) lehettek, akik elökészítették a terepet, és előőrsei, elökészítői voltak a későbben működő nevezetes hutának. A fordulat éve 1797, amikor feltűnően megugrik a kereszteltek száma. 1799-ben 7, 1800-ban 11. Ezek azok évek, amikor biztonsággal állíthatjuk, hogy a huta már létezik. Vagyis a vitráriusok (üvegmunkások) száma annyira bővül, hogy már biztosítja az üzem rendszeres müködését. Lukafa lakosságának a bővülését bizonyító egyházi bejegyzések alapján - még ha a szülők foglalkozása nincs is feltüntetve - elfogadhatjuk Winkler tudósítását, miszerint a „Glashütte” Lukafán 1799. január 21-én kezdte meg üzemszerü müködését. Lukafa így 1800-ra Dunántúl egyik legjelentősebb üvegtermelő településévé vált. ${ }^{47}$ A lakosság becsült létszáma ekkor 250 körülire tehető.

1821-től Ibafán - amikor Lukafát az itteni plébániához csatolják - az anyakönyvekben már pontosan fel vannak tüntetve a foglalkozások is: vitráriusok, üvegmetszők, üvegfúvók stb. Ezek a foglalkozások aztán 20 év múlva, 1841-ben az ibafai bejegyzésekből egyszerre eltűnnek. A régi nevű egyénekből maradnak ugyan né-

44 „Lehmann, uo. „II. József rendeletére 1784-ben Munnichsmeyer tüzértiszt által készített térkép...”; H. J. Gy. Kéziratrészleg, 49. p. : „....az említett József császár korabeli térképen néhány ház látható Lukafa néven a térképen."

45 Gödrekeresztúr és Gödre régen külön falvak, ma Gödre néven egyazon település. Gödreszentmárton töle néhány $\mathrm{km}$-re délre uradalom és külön község. A templomos hely régebben: Gödrekeresztúr.

46 H. J. Gy. Kéziratrészleg, 51-52. p.

47 H. J. Gy. Kéziratrészleg, 54-55. p. hányan, de ezeket néhány évig kizárólag mind hamuégetőként tüntetik fel. Okát jól ismerjük - írja Horváth J. Gyula. Az ibafai plébánia levéltárában ugyanis van egy iskolarendtartási napló, amelyben megjegyzik, hogy Lukafán tanítás nincs, mert a szülök Szentmihályfára költöztek. Az 1841. évi kétújfalusi egyházi anyakönyvi bejegyzésekben (Szentmihályfa-puszta ehhez a plébániához tartozik) valóban megjelennek a lukafaiak, akik „in domo vitraria” (az üveghuta telepén) laknak és dolgoznak. A kétújfalusi és az ibafai anyakönyvekből aztán azt is megtudjuk, hogy néhány évi itteni tartózkodásuk után a manufaktúra feloszlott (1856), és az üvegesek jó része visszament Lukafára, vagy szétszóródott az ország más üveghutáinak valamelyikébe. ${ }^{48}$

A későbbiek (XIX. század) során az üveghuta (gyár) működése, átmeneti megszűnése, a keménycserépedény (porcelán) üzem megjelenése, az üvegkészítés ujrakezdése, majd az üzemrészek végleges bezárása függvényeként a település népessége erősen ingadozott. A rendelkezésünkre álló adatok, föleg a pécsi egyházmegye sematizmusai, az ibafai Visitatio Canonica (püspöklátogatások) jegyzőkönyvei alapján 1830-tól az alábbiak szerint alakult:

\section{192 katolikus, 75 ortodox (cigány), összes: $267(?)^{49}$}

1840. 188 katolikus, 19 zsidó, összes: $207 . .^{50}$

1846. Összes:185. ${ }^{51}$

1847. Összes 65 (?) (A szám elírás lehet, valószínűen: 165). ${ }^{52}$

1850. Összes: 257 . Ebből 187 német, 70 magyar ${ }^{53}$

1851. 190 katolikus. ${ }^{54}$

1857. 141 katolikus, 15 zsidó, összes: $156 .^{55}$

1861. Összes lakó: $267 .^{56}$

1867. 252 katolikus, 10 zsidó, összes: $262 .{ }^{57}$

Az egyházi bejegyzések alapján tudjuk, hogy az üveg- és cserépedényt készítő szakmunkások többsége Szudéta-vidékröl származó katolikus német. ${ }^{58}$ Több hullámban érkeznek. A kis falu üzemi, családi és hétköznapi nyelve a XIX. század végéig is német, eltérően a közeli, kiegészítő munkát folytató, Lukafa-pusztán (Deszkametszőn) élő uradalmi cselédségtől, amely magyar.

Említettük: a Mecsekben, a Zselicben a XVII-XIX. századi hamuzsírfőző helyek és erdei üvegcsürök alapítói uradalmak, céljuk a kihasználatlan erdők ipari hasznosítása és új irtásföldek nyerése. Létesítésüket

48 H. J. Gy. Kéziratrészleg, 54. p.

49 H. J. Gy. Kéziratrészleg, 58. Ibafa, Visitatio Canonica, 1830

50 H. J. Gy. Kéziratrészleg,59.(Pécs, Egyházmegyei Sematizmus névtára, 1840

51 Lehmann Antal: Adatok a Szentlukai üveghutáról (1807-1808).

52 H.J.Gy. Kéziratrészleg, 58. Ibafa,Visitatio Canonica, 1847.

53 Lehmnann Antal: XIX.Századi üveghuták a Zselicben. 94-95.

54 Fényes Elek: Magyarország geographiai szótára, II. Pest, 1851. 50.

55 H.J.Gy. Kéziratrészleg, 60. (Pécs, Egyházmegyei Sematizmus alapján.

56 Lehmann Antal: Adatok a szentlukai üveghutáról (1807-1808)

57 H.J.Gy. Kéziratrészleg, 60.(Pécs, Egyházmegyei Sematizmus alapján.)

58 Lehmann, ua. 117.p.; Raichl Sándor uradalmi intéző szerint (1969), az üveg és porcelán szakmában Schwarzwaldból származó németek is dolgoztak 
bizonyos földrajzi és technológiai tényezők is meghatározták. Mivel az üveg egyik értékes alapanyaga a fa - elsősorban bükkfa -, a huták a hamuzsír készítéshez és a kemencék fütéséhez nélkülözhetetlen erdőkbe települtek. Müködésükhöz szükséges víznyerés okán azokat mindig völgybe, bővízü forrás vagy patak mellé építették. Fontos szempont volt az is, hogy az üveggyártás másik alapnyaga a kvarchomok, közel legyen bányászható. A nyersanyag és készárú szállítása érdekében, ugyancsak meghatározó szerepe volt a közlekedésnek, a viszonylag jól járható utak közelségének. Az egymástól csupán $3 \mathrm{~km}$-re található Németlukafa és Szentluka-puszta adottságai sokban megfelelnek a követelményeknek. A fából (föképpen a bükkfából) égetett-fözött káliumkarbonát vagyis hamuzsír, korlátlan mennyiségben volt előállítható. „... a homok is helyben volt, ugyanis a Zselicben sok helyen a felszínen, vagy közel a felszínhez elöfordul a pannon- és levantei korból származó, nagy szilikáttartalmú homokféleség." 59 (A lukafai huta egyik felszíní homoknyerő helye (a Homokos-gödör) mindössze 200-300 méterre, míg a másik $2 \mathrm{~km}$-re, a Jámborka nevű dülörészben volt. $A$ huta müködéséhez és a cserépedény gyártáshoz szükséges agyagféleség részben a patak másik oldalán, ugyancsak néhányszáz méterre lévő, későbbi téglavető helyén volt kinyerhető. Az építkezésekhez szükséges könnyebb fenyőanyagot: - gerenda, léc - ugyancsak az uradalom akkor még kiterjedt fenyőerdei biztosították.)

Mindkét „Szent Lukácsról - Lukáról” elnevezett erdei huta, a zselici fővízválasztó két oldalán feküdt. Szentluka a gerinc északi, Lukafa a déli oldalán. Szentluka éltető forrása és patakja észak felé a Surjánpatakba, majd a Kaposba, később a Sióba folyik, azzal együtt a Duna vízrendszeréhez tartozik. A gerinc déli oldalán Lukafa, Sasrét forrásaiból és több más ágból kialakult Almás-patak vízrendszere előbb a Gyöngyössel, majd Okorág táján csatlakozva a Fekete-vízzel a Dráva vízrendszeréhez kapcsolódik. ${ }^{60}$ A lukafai „öveggyárat” a Cigánykút-nak nevezett ugyancsak közeli, bővízű forrás látta el szükséges vízmennyiséggel. ${ }^{61}$

A vízválasztó gerinc szintén kedvező földrajzi adottság, ugyanis azon vezetett a Kaposvárt Péccsel összekötő főút (A nagytótvárosi elágazásnál Lukafa mindössze másfél km.) Nagyrészt egész évben járható volt, természetesen földút lévén, eső és hóolvadás után hamar kiszáradt. ${ }^{62}$ Ami még ennél is lényegesebb volt, hogy gyakorlatilag egész hosszában minden mütárgy (híd) nélkül ért célhoz. A hajdani „országút” mentén megfelelő távolságra csárdák álltak, amelyek mellett kis „dombháti soros falvak” (Helesfa, Korpád, Szabás, Tótújváros v. Nagytótváros, stb.) jöttek létre. ${ }^{63}$

59 Lehmann, ua. 94-95. p.

60 H. J. Gy. Kéziratos vázlat

61 A Cigánykút-forrást és az Almás-patak másik forrását Sasréten Sajgó Ferenc a Mecseki Erdészeti ZRT.igazgatója és baráti köre újította fel 2000 körül.

62 H.J.Gy. Kéziratos vázlat: "Kivétel volt a gálosfai átkelö, ahol le kellett ereszkedni a völgybe, és tengelyig érö sárban kellett a másik gerincre felkapaszkodni. Hallomásból ismeretes, hogy az átkelöhelyen egy különös foglalkozás született. A völgy alján egy négyökrös fogatos gazda várakozott, aki a feneketlen sáron - nyilván tarifa ellenében átvontatta az arrajáró kocsikat, mint valami szárazföldi révész."

63 H. J. Gy.Kéziratos vázlat
A lukafai üveghuta virágkora az 1800-1830 közötti évekre tehető. Az 1830. évi ibafai Visitatio Canonica (amikor a látogatást Szepesy lgnác pécsi püspök végezte), említésre méltónak találja feljegyezn: „Lukafa fiókegyházban található egy üvegkohó, amely egyedülálló az egész egyházmegyében."Addigra ugyanis a püspöki üveghuták (az óbányai és a kisújbányai) megszüntették müködésüket. ${ }^{64}$ Ezekben az évtizedekben Lukafán iskola müködött, amelyről az 1830. évi Visitatio Canonica egyik fejezete részletesen tudósít. Ezek szerint akkor Lukafán 30 iskoláskorú gyermek van, akik közül 15 valóban jár iskolába. A lukafai tanító (magister) Streitenberger János, született Mucsiban 1768-ban, segédtanító volt Závodon, tanított Köblényben és Bőszénfán. Az okmány megjegyzi, hogy zenében jártas és nős. Járandósága az üvegüzem munkásaitól páronként 4 forint, a hamuégetőktől 2 forint. Minden iskolábajáró gyerek után kap egy iskolai évre 30 krajcárt. A tanító egy uradalmi házban lakik, amely az összedőléshez áll közel. Ugyanaz a helyiség szolgál a tanító lakásául, amelyben a tanítás is folyik. Temetésért kivétel nélkül mindenkitől 30 krajcárt kap. (A tanítás nyelve nagy valószínűséggel: német.) $\mathrm{Az}$ 1847. évi ibafai Visita Canonica már azt jegyzi fel, hogy „Lukafán az iskola megszünt.”65

Az 1847. évi Visita Canonica arról is hírt ad, hogy Lukafán van egy 75 font súlyú harang, ,amely mindeddig nincs megáldva. ${ }^{66}$...Temetöje 44 négyszögöl és sövénykerítése van. Egy fából készült keresztet 1820-ban állitotta Jöckl Miklós.” Horváth J. Gyula ezzel kapcsolatban megjegyzi: „Ezt a kicsiny temetőt valószínüleg kibővítették, mert még sokáig szolgált temetőül. lgaz, hogy az 1960-as években már régi sírok helyén temettek. Egy ilyen felbontott sírban találtam kis üvegmécsest és üveggyöngyöket, amelyek Lehmann Antalhoz kerültek. De én magam is jó egynéhány halottat temettem a lukafai temetöben...Az utolsó temetés itt 1966. jan. 24én történt,... azóta a lukafai halottakat az almamelléki temetőben temetik el." ${ }^{67} \mathrm{~A}$ ma is álló faragott kőből álló, későbbi temetői nagykereszt olvasható felirata: „Állittatta ... M... Julianna, 1909”. A manufaktúra jobbmódú családjai általában német nyelvű kőkereszteket állítottak. Aschenbrenner József (1840-1910) valószínűen vezető beosztásu „vitrárius” vagy „porcelános” márványkeresztje és ugyanezen családból származó, 33 éves korában elhúnyt Aschenbrenner Gyula (1873-1906) „áldozár” (felszentelt rk. pap) sírfelirata viszont magyar nyelvü. ${ }^{68} \mathrm{Az}$ „üveggyáriak” sorában egy harmadik kibe-

64 H. J. Gy.Kéziratrészleg, 57.p.

65 H. J. Gy. Kéziratrészleg, 57-58. p.

66 H. J. Gy. Kéziratrészleg. 59. p.; A szájhagyomány szerint a lukafai harangot a szomszédos Szentmárton-pusztán a Templomhegyitáblában találták a XIX. sz. elején. A sérült harangból az üveggyári munkások egy kisebb, új harangot öntettek maguknak. Innen az emlékezések eltérnek: Egyik variáció szerint a harang az 1900-as évek elején Szentmárton-pusztára került, onnan 1990 körül Almamellékre, jelenleg az ottani temetői haranglábon található. Mások szerint a Terecsenybe átköltözött üveggyári munkások vitték magukkal, és ma is az ottani harangláb lakója. (Adatközlő: Mózs Ferenc majorgazda, 57 é. Almamellék, Szentmárton-puszta. Gyüjtő: Eperjessy Ernő,1961.

67 H. J. Gy. Kéziratrészleg, 59. p.

68 A jellegzetesen németlukafai családnév: „Aschenbrenner” magyarul „hamuégetőt” jelent, amely nevet esetleg már Magyarországra költözésük után, foglalkozásuk alapján kapták. 
tűzhető kőkereszten Kreiner Antal (...-1913) neve szintén magyar nyelven íródott. A huta egykori halottainak sírjait még az 1930-40-es években is, a kohók faláról egykor levert öklömnyi, zöldszínü üvegtömbökkel díszítették. ${ }^{69}$ A Bassler (később: Baracs) sasréti főerdész család 1930-as években itt eltemetett 3 családtagja emlékére 2010-ben állított rusztikus sírkövet. ${ }^{70}$

Azt tudjuk, hogy a hanyatlás évei után 1841-ben jelentős számu „vitrárius” és „Zingarus” hagyja el Lukafát, költözik át Szentmihályfára az ottani üveghutához. Nyílván a gyermeklétszám is jelentősen csökkent. $A$ volt lukafai nevek pedig elöször jelennek meg Terecsenypusztán, Ibafán és más környékbeli településen. ${ }^{71}$

Az egyházi sematizmusok tanúsága szerint a lukafai üveghuta ezután sem szűnik meg teljesen, hanem az idöközben beindult keménycserép (kőedény, porcelán) üzemmel párhuzamosan müködik tovább.

Az 1847. évi Visitatio Canonica (Scitovszky János pécsi püspök látogatása vagy bérmaútja alkalmával) a fiókegyházak közül Lukafáról szintén fontosnak tartja megemlíteni: „Lukafa predium, ubi celebrisz est ustrina in tete Comitatu unica - Lukafapuszta, ahol a nevezetes huta van, ez a kohó egyetlen a megyében. ... a település lakói németül beszélnek." 72

Ugyanez a vizitáció a szülésznő helyzetével is foglalkozik. (Ebben az évtizedben már törvény írja elő, hogy minden jelentős településen képzett szülésznőnek kell lenni, melynek ellenőrzésére a polgári hatóság a püspököt kérte fel.) Ennek köszönhetöen névszerint tudjuk, hogy Lukafának és Korpádnak közös szülésznője Scherdán Magdolna. ${ }^{73}$

Az újkori erdei üveghutákban, (helyszíni cserépmaradványok alapján Lukafán is), elsősorban úgynevezett káliumüveget készítettek. Vagyis az üveggé olvasztható szilikátot - homokot vagy kvarckavics (békasó) zúzalékát - hamuzsírral (sal alkali) és mészporral keverték. A homokban található vasoxid miatt zöldes árnyalatu üveget kaptak. Az átlátszó fehér, zöld, barna és másszínű üveghez különféle adalékokat (mangándioxid, arzén, konyhasó, salétrom, földpátok stb.) adtak. A kékkő (rézszulfát) például kék színüre festette az üveget. ${ }^{74}$ Az egykori lukafai üveggyár terülén (kertekben, temetöben, vízmosásokiban, stb.) a XX. században is bőséggel talált cserepekböl következtethetünk arra, hogy Lukafán tömegesen termelt zöld, barna és fehér átlátszó üvegek mellett igényesebb kékszínü, sőt rubinszínü használati- és dísztárgyak is készültek. ${ }^{75}$ A kemencék termelése nem volt folyamatos. A kohók a nagy hő következtében időnként megrepedtek, ilyenkor leállították, a falára merevedett üvegtömböket leverték és újrahasznosították, a kemencéket átépítették. Lukafáról a huta közelebbi termelési adataira utaló levéltári hagyaték (számla, leltár, stb.) eddig nem került elő, miként Szentlukán, Hárs-

69 Eperjessy Ernő adatai.

70 Ráczné Gádor Gyöngyvér (Mike) szíves közlése, 2012. Sírfelirat Bassler Ernst főerdész, 1855-1938 - felesége Bitterlich Franciska, 1860-1944. - unokájuk Bassler Edit, 1919-1934.

71 H. J. Gy. Kéziratrészleg, 54-55. p.

72 H. J. Gy. Kéziratrészleg, 58. p.

73 H. J. Gy. Kéziratrészleg, 58-59. p.

74 Lang, ua. 14-15. p.

75 Hauser Mátyásné Frigyesi llona Lukafán gyüjtött üvegcserép gyüjteménye alapján. (Ibafa, 2011.) - Eperjessy a lukafai kertekben 1938-ban 6-8 cm-es, kékszínü állatszobrocskákat talált. ágyon, vagy Bakócán. Viszont azok termékszerkezetéből következtethetünk arra, hogy tömegáruként Lukafán is elsősorban a keresett használati tárgyak: öblösüvegek (sörös és boros palackok, demizsonok, savanyúság és ruszli tárolására alkalmas többliteres edények, butéliák, boros és vizes poharak, söröskorsók, vizeskancsók, orvosságos üvegcsék, sótartók, mécsesek, lámpák, cilinderek, stb.) és táblaüveg (ablaküveg, tükrök) gyártása folyt. Ez utóbbit az ugynevezett nyújtókemencékben terítették ki. Ezenkívül kisebb mértékben fúvott és csíszolt felületű dísztárgyak (vázák, emlékpoharak, szobrocskák, stb.) is készülhettek. Horváth J. Gyulát az 1970-es években felkereső lengyel kutatók feltételezése szerint egyidőben Lukafán „hinterglasok” (táblaüvegre festett szentképek) is készültek. ${ }^{76} A z$ üveghuta termékeinek fő vásárlói kocsikon szállító zsidó kereskedők, házaló üveges „tótok”, akik főleg Somogy, Tolna és Baranya vármegyékbe, Bácskába és Szlavóniába juttatták el a lukafai üvegárút. Raichl Sándor szerint az egyik legnagyobb felvevő piacuk a Balkán volt. ${ }^{77}$

A lukafai üveggyártás virágkora bizonnyal 1800 és 1830 közöti időszakra esik. A későbbi években - bár nincsenek rá adataink -, a gazdaságtalan termelés miatt az üvegkohó tevékenysége visszaszorul, majd átmenetileg meg is szünik. Ez mellett szólnak az ibafai egyházi adatok, melyek szerint Lukafáról a vitráriusok (az üvegszakmában dolgozók), hamuzsírfözők és cigányok 1841-ben egyszerre eltűnnek. Neveik ugyanabban az évben a kétújfalusi egyházi anyakönyvekben jelennek meg, akik „in domo vitraria” (az üveghuta telepén), azaz Szentmihályfa-pusztán élnek és dolgoznak.

A visszamaradtak később az egyházi anyakönyvekben kizárólag mint hamuégetők szerepelnek. - írja Horváth J.Gyula. ${ }^{78}$ Az üveghuta hanyatlása idején, feltehetően a termelés kiesés ellensúlyozására 1840-es években Lukafán kerámia (kőedény) manufaktúra is létesül. Az alapító tőkések tekintetében az egyes kutatóknál eltérő adatokat találunk. Horváth J. Gyula alapítóként Spitzer és Wohlheim kaposvári vállalkozók nevét jelöli meg. ${ }^{79}$ Lehmann Antal viszont azt írja: „...1846ban Auer bécsi, Cvetkovich pécsi és Koharich szigetvári kereskedők által létesitett cserépedénygyárral együtt..., ez utóbbinak berendezése egy későbbi vásárlás útján Pécsre kerültek, hogy velük megalapitódjék a világhírü Zsolnay Porcelángyár." ${ }^{80}$ A kis üzem nem paraszti fazekasedényeket készít, hanem a pénzesebb polgárság céljaira igényesebb keménycserép edényeket és fínom porcelán tárgyakat (úri étkészlet, tányér, tál, bögre, csésze, lámpa, pipa, dísztárgyak, stb.) gyárt.

76 H. J. Gy. személyes közlése alapján. (Adat:Eperjessy)

77 Raichl Sándor a Biedermannok uradalmi intézője szerint, - aki az 1920-as években visszamenőleg tekintette át a lukafai üveggyár és porcelángyár gazdálkodását - „... a legnagyobb felvevő piac a Balkán volt." (Gyüjtő: Eperjessy, 1969.) - A sasréti cselédházban, - amelyben korábban az"öveggyárat" kiszolgáló kocsisok laktak -, 1932-ben ott lakó Eperjesi és Fodor család az üzemből származó, kb 50 db zöldszínü, 7 dl-es sörösüveget talált elrejtve az erdőben, amelyen „Dreher Sándor Serfözdéje, Köbánya...” felirat volt. A családok a „kincsleletet” az 1960-as években is paradicsomfözéshez használták.

78 H. J. Gy. Kéziratrészleg, 54.p.

79 H. J. Gy. Kéziratrészleg, 55. p.

80 Lehmann, ua. 96. p. 
A lukafai manufaktúra híre és üzemmenete nem lehetett rossz, amelyre abból is következtethetünk, hogy Spitzer és Wohlheim, „Lukafai üveglerakat” ${ }^{11}$ cégtáblával egy fényes üveg- és porcelánüzletet is alapított Pécsett. Az üzlet egészen a második világháború végéig létezett, a tehetősebb középosztály igényeit elégítette ki. Müködése évtizedeiben a lukafai üzemböl az év nagy részében használható utakon szállították ide a kiváló árút. Az üzleti elnevezést az üveggyár és cserépedény manufaktúra felszámolása után is megtartották. A pécsi születésű Horváth J. Gyula emlékezete szerint az üzlet Pécsett a Király utcában, vagy inkább a Színház-téren volt található, ahol az 1990-es években egy Kalóz nevű kaszinó müködött. ${ }^{82}$

Amint az anyakönyvi bejegyzésekböl kitünik, 1847ben a lukafai „Porzolán Fabrikának Főfölügyellője” Cvetkovitz Ferentz, akinek Adelhaid, Therezia, Beatrix nevü leánykáját 1847. május 13-án tartják keresztvíz alá Ibafán. A gyermek anyja Pheffer Josephina, keresztszülei pedig Koharits Károly „Szigethi Kereskedő” és Pheffer Therezia. Ez időből való anyakönyvek más „porcelánosok” nevét is megőrízték. Közülük itt fontosnak tartjuk még kiemelni Berger István nevét, aki az anyakönyvi bejegyzés szerint „Gyár elnök”. Neje Vagner Borbála, gyermeküket 1848. febr. 15-én keresztelik Ibafán. Az utolsó porcelános neve 1860-ban olvasható az ibafai anyakönyvekben. ${ }^{83}$ A Lukafai „üveggyár” illetve „kerámia üzem” múltja itt kapcsolódik a világhírü Zsolnay-gyár történetéhez. Zsolnay Teréz - M. Zsolnay Margit: Zsolnay c. családtörténeti kötetében Zsolnay Ignácról azt olvashatjuk: „...elvégezte a magyaróvári mezőgazdasági akadémiát, majd Lukafán fazekas mesterséget tanult." ${ }^{84}$ A következő „Lukafa megvásárlása, a pécsi üzem megalakulása"címü fejezetben azt írja: „Ez időtájt kereste fel nagyatyánkat (ti. Zsolnay Milóst) Cvetkovich Ferenc tekintélyes pécsi polgár, aki kapcsolatban állt a lukafai kis agyagárú manufaktúra tulajdonosával ..., Spitzerrel. Azt ajánlotta nagyatyánknak, hogy vegye meg lgnác számára ezt a kis manufaktúrát. $A$ vételár meghaladta nagyatyánk vagyoni lehetőségeit, azért más megoldást keresett. Ignác egy évet töltött Lukafán, hogy megtanulja az agyagárúk gyártását." 85 (Ismeretes, hogy ugyanez a Cvetkovich Ferenc korábban a lukafai üzem „Föfelügyellője” volt.)

„Amikor aztán a lukafai manufaktura berendezése csakugyan eladásra került, nagyatyánk a felszerelési tárgyak többségét megvásárolta, szekereken Pécsre szállittatta és ideiglenesen a téglavető mellé rakatta le. "86 Így kerültek a lukafai manufaktúra agyagipari eszközei részben Pécsre és lettek a hírneves Zsolnay-gyár első gépi berendezései, 1854-ben.

A lukafai üzem minőségi termelésére Zsolnay Teréz azon utalásából is következtethetünk, miszerint „...a Littke-család birtokában van két kráter alakú talpas

81 Utolsó tulajdonosa: Inselt ... volt, akit 1944-ben Auschwitzbe deportáltak. H. J. Gy. kéziratából.

82 H. J. Gy. Kéziratos vázlat; - E tanulmány társszerzője, Eperjessy Ernő még 1948 júniusáig is naponta látta a feliratot, mivel Pécsett a Király utcában arra tette meg az utat a tanítóképzőbe.

83 H. J. Gy. Kéziratrészleg, 55-56. p.

84 Zsolnay Teréz - M. Zsolnay Margit: Zsolnay. A gyár és a család története, 1863-1948. Corvina. Gyoma, 1974. 10-12. p.

85 Zsolnay Teréz - M. Zsolnay Margit, ua.10-12. p.

86 Zsolnay Teréz - M. Zsolnay Margit, ua. 10-12. p. váza, amelyeket lgnác még Lukafán készített." Ugyancsak itt olvasható, hogy lgnác az üzem szervezése során úgy véli, „....ugyanolyan szép edényt fogok gyártani, mint amilyent Lukafán állítottam elő." ${ }^{87}$

A kerámia (porcelán) üzem eladása (1856) után az üveghuta ujabb 20 évre mégegyszer feléled és termel, mely idő 1869-től 1888-ig tartott. ${ }^{88}$ L. Imre Mária: Adatok a baranyai üveghutákhoz c. tanulmánya Horváth J. Gyulától kapott adatokra hivatkozva közli, az egyházi anyakönyvek alapján kikövetkeztethető, ebben a 20 évben Lukafán üvegesként dolgozók létszámát:

1869: 6 fö; 1870: 12 fö; 1871: 7 fö; 1872: 9 fő; 1873:6 fö; 1874: 9 fö; 1875: 7 fő; 1876: 7 fő; 1877: 8 fő; 1878: 6 fö; 1879: 5 fö;1880: 8 fö; 1881: 11 fö; 1882: 6 fő; 1883: 10 fö;1884: 7 fő; 1885: 9 fö; 1886: 7 fö; 1887: 6 fö; 1888: 6 fö. ${ }^{89}$

$\mathrm{Az}$ üveghuta végleges megszűnésére vontkozó bizonyos források adatai ellentmondásosak. A Soproni Kereskedelmi és Iparkamara 1880. évi jelentése szerint a lukafai „gyár" 1880-ban megszünt. ${ }^{90}$ Ugyanakkor Telkes Simon: Üvegiparunk címü monográfiájában arról ír, hogy a "gyár" 1884-ben még tíz évre szóló állami kedvezményt kapott, ennek ellenére tönkrement. ${ }^{91}$ A soproni kamara 1891. és 1892. évi jelentése azt állítja, hogy a lukafai üveggyár bérlő hiányában szünetel..$^{92}$ Vargha Károly: A Délkeleti Zselic c. monográfiájában családi emlékezésekre hivatkozva írja: „Az üzem azonban, amelyet a Spitzer és Wohlheim cég bérelt és amely termékeivel ellátta a vidéket, - az 1887. év őszén megszünt." ${ }^{93}$ Horváth J. Gyula az egyházi anyakönyvi bejegyzésekre hagyatkozva az 1888-at fogadja el, ugyanis Lukafán 1888-ban szerepel utoljára szülőként vitrárius.

Horváth J. Gyula azt is vizsgálta, hogy az üzem megszünése után hova lettek a vitráriusok. A hagyományok tudni vélik, hogy báró Biedermannék az elvándorló szakmunkásoknak bizonyos „végkielégítést” fizettek. Voltak családok, akik azidőtájt Szlavónában (Dráván túl) a magyar kirajzásokhoz (vagy ottani német csoportokhoz) csatlakozva, olcsó földet vásároltak. Néhányan az ittmaradó rokonsággal a második világháborúig is kapcsolatot tartottak. ${ }^{94}$ Több német családot Terecseny-pusztán (valószínű az Arnold, Kreiner(Krajner), Haslinger, Deutschmann, Kirsch, Hirsch, Göndötsch, Lehr, Metz, Schweitzer, Jeger, Gieber, Weber stb.) a Biedermannok kiparcellázott birtokrészén három hold földdel és házhellyel kárpótolták. Az egy hold rétet bérbe kapták, aminek ellenében (hogy az uradalom munkaerejét biztosítsák) téli és nyári napszámra, ugynevezett „robotra” kötelezték őket. Ezek a terecsenyi zsellérek és leszármazottaik

87 Zsolnay Teréz - M. Zsolnay Margit, ua. 13. p.

88 H. J. Gy. Kéziratrészleg, 56. p.

89 Dr. Imre Mária: Adatok a baranyai üveghutákról .... 2.p.

90 H. J. Gy. Kéziratrészleg, 60. p.(Forrásmunka megjelölése nélkül.)

91 H. J. Gy. Kéziratrészleg, 60. (Forrás megjelölés nélkül.)

92 H. J. Gy. Kéziratrészleg, 60. p. (Forrás megjelölés nélkül.)

93 Dr. Vargha Károly: A Délkeleti-Zselic. Csurgói Könyvtár XVII. kötet, Kaposvár, 1941. 32. p.

94 Egyik Szlavóniába átköltözött Zimmer nevű „vitrárius” család a második világháborúig levelezett az Almamelléken maradt Zimmer rokonsággal. 1944-ben a jugoszlávok a szlavóniai Zimmer családot, mint „magyart” kiüldözték. Magyarországon Almamellékre menekülve, 1945-ben őket („Vastaglábú” Zimmeréket) abba a rokon Zimmercsalád házába telepítették, amelyböl az ittenieket, mint németeket kilakoltatták.(Eperjesi János, Horváth J.Gyula szóbeli közlése.) 
1945-ig évente bizonyos számú lovasfuvarral (robottal) tartoztak dolgozni a Biedermann-család erdészetében. ${ }^{95}$ Több család a környékbeli német nyelvü falvakban (Almamellék, Bőszénfa, Boldogasszonyfa, Ibafa, Csebény, stb) földműves zsellérként telepedik meg. Voltak, akik mesterségük révén az ország más üveggyárában kerestek munkát. Az emlékezések szerint föképpen Ajkára kerültek. Az ibafai kereszteltek anyakönyvi adatai szerint egy ideig Lukafán is maradtak vitráriusok, akik ezentúl „operariusok”, azaz napszámosként élnek tovább. ${ }^{96}$ Horváth J. Gyula jegyzetei alapján az 1890-es években még Lukafán található szülők illetve keresztszülők: Adamus Teller et Katharina Pufler oper. - Vencellus Eizner et Rosalia Tillinger oper. - Petrus Veibl et Marianna Jeger operar. - Josephus Veininger et Eva Feld operar. - Joannes Flam et Julianna Schleer oper. - Jacobus Hoffman et Elizabetha Schveizer oper. - Franciscus Eizner et Elisabetha Speigl oper.- Schlegl Mihály és Dunszt Éva napsz. Gausz Antal és Herczeg Anna napsz. - 1900ban a falu kocsmárosa Eizner Vencel és Tillinger Róza. 1891-ben a közeli Tótvároson lakik Carolus Pufler et Catherina Schler operar. ${ }^{97}$ Valószínü, hogy Horváth által az ibafai anyakönyvekből kigyüjtött 11 családon túl is maradtak Lukafán egykori üveg és porcelános családok. Ez mellett szólnak a temetőben Aschenbrenner József (1840-1910), Aschenbrenner Gyula (18731906), és a 44 éves Kreiner Antal (...-1913) feliratú sírkövek is. Raichl Sándor uradalmi intéző 25 olyan üveggyári munkásról tudott még, akik 1900 körül Lukafán maradva, napszámos munkát vállaltak az uradalomban.

Az első világháború táján Lukafáról ezek a nevek is eltűnnek. Az utolsó vitrárius Franz Propst és felesége Maria Frischl. Propszt Ferenc 90 éves kor felett, kb.1936 táján halt meg Lukafán, ott is temették el. Jóval fiatalabb felesége Bassler Ernő főerdészéknél háztartási alkalmazott lett Sasréten. ${ }^{98}$ Későbben egy név kanyarodott még vissza. Az 1940-es években Eisner György (felesége Zimmer llona) mint uradalmi kovács szolgált ugyanabban a „hajtott házban”, amelyben ősei kocsmárosok voltak az üveggyár idején. ${ }^{99}$

$A z$ erdei üveghuták bezárását a XIX. sz. végén a racionálisabbá váló erdőgazdálkodás is siettette. Az 1880-as évek elején Lukafára került, erdészeti akadémiát végzett főerdészt, Bassler Ernőt „megdöbbentette az az óriási mennyiségü, de leginkább minőségi pusztulás, amit a huta az erdőben maga után hagyott, ... egyértelmüen ellensége volt a huta müködésének."

95 Raichl Sándor volt uradalmi intéző adatai, 1969. (Gyűjtő: Eperjessy)

96 H.J. Gy.Kéziratrészleg, 61. p.

97 H. J. Gy. Kéziratrészleg, 61. p.; Lukafai temetö 2012-ben is fennálló két sírkeresztjének tanúsága szerint az Aschenbrenner család még 1910-ben is Lukafán lakott. (Figyelemre méltó a család „beszédes" neve: aschenbrenner, magyarul - hamuégető.) Ez a családnév a XX.sz. elején a Biedermannok szentmártoni uradalmában tűnik fel ismét, mint gazdasági vezető. 1940-45-ben Szigetváron is élt Aschenbrenner család báró Biedermann Imre alkalmazásában. Tihanyi Attila és Könyves Kálmán szíves közlése szerint, Németlukafa (falu) utolsó lakóját is Aschenbrenner-nek nevezték. (Aschenbrenner Jenő erdész, az 1970-es évek végén költözött el a Szentegát melletti Hamuházára!)

98 Eperjessy Ernő személyes emlékezése.

99 Eperjessy személyes emlékezése.
Az emlékezés szerint: „... amikor az utolsó vitráriusok elmentek (vagy az uradalomban más munkán helyezkedtek el), minden hutai épületet már a következö évben sürgősen lebontatott. Amikor aztán hamarosan ismét megjelentek a zsidók, hogy az üveges munkát folytassák - mondja Boder(Bodor) József, - Bassler már azt felelte, hogy újrakezdeni nem lehet, mert már minden épületet lebontottak." 100

A cigányok lukafai megjelenésére vonatkozó, első írásos bejegyzést a gödrei, pontosabban gödrekeresztúri egyházi anyakönyv örzi: 1790. március 1 . A keresztelt gyermek szülője Kalányos Miska. Az ibafai plébánia levéltárában található, 1830. évi Visitatio Canonica bejegyzése szerint ebben az évben 192 latin rítusu katolikus hívő lakik Lukafán, a görög rítusu, azaz görög keletiek száma pedig 75 . Az anyakönyvi adatok minden esetben a cigányoknál jelzik a görögkeleti vagy pravoszláv vallást. Ezek aztán lassan a többségi római rítusra térnek át, illetve ilyennek írják át és kezelik őket az ibafai plébánosok. Az 1857-ben kiadott egyházmegyei sematizmusok szerint az ibafai plébánián már nincs pravoszláv vallású bejegyzett személy, de foglalkozásuk rovatban minden esetben „Zingarus” áll. ${ }^{101}$

Az arányaiban jelentős „Zingarus” bejegyzés nemcsak etnikai hovatartozást, hanema hamuzsirégetéshez, valamint a huta és cserépedény kemencékhez szükséges kiegészítő foglalkozást: fakitermelő (favágó), illetve egyszerü faeszközöket (teknőket, vályukat, lapátokat, stb.) készítő mesterséget is jelentett.

„Arról persze fogalmunk sem lehet, hogy ezek a cigányok honnan származnak, hiszen nevük egyáltalán nem jellegzetes (Orsós, Kalányos, Buzás)" - írja Horváth. ${ }^{102}$ Azt tudjuk, hogy az üvegesek és fazekasok Németlukafán a huta, az üvegcsür és cserépedénygyár közelében laktak, amit a mai napig is „falunak” nevez a nép.Tőle $1 \mathrm{~km}$-rel délebbre fekvő Lukafa-pusztán sohasem lakott vitrárius. Viszont elkülönülve itt laktak a cigányok, majd később uradalmi cselédekké váló elemek, a huta igavonó szükségét ellátó kocsisok, béresek és pásztorok.

Mai meghatározással a román nyelvü „beás” cigány etnikum az üveggyár megszünésével sem tűnt el teljesen. Maradékaikat Br. Biedermann Rezső a XIX. sz. végén Lukafáról a 4-5 km-re lévő Terecseny-pusztai birtokára, az erdő szélére telepítette. Ott készítvén maguknak putrit, a lakhatás és hulladékfa-gyűjtés ellenében, a bárói birtokon putrinként havi egynapos robottal tartoztak 1945-ig, (ami rendszerint erdei munkát, vagy a sasréti kastély és iskola részére végzett favágást jelentett). ${ }^{103}$

100 Boder (Bodor) József, közel fél évszázadig volt Németlukafán erdész. Rá hivatkozva: H. J. Gy. Kéziratrészleg, 60. p.; Családi viszszaemlékezés alapján ugyanezt erősíti meg Bánki László (Budapest, 2007.), akinek nagyapja Bassler Ernő Lukafán föerdész volt, apja pedig Bánki (Bassler) Rezső az 1880-as években, már ott az egyik vezető vitrárius megüresedett házában született.

101 H. J. Gy. Kéziratrészleg, 50. p.

102 H. J. Gy., Kéziratrészleg. 51. p.

103 Raichl Sándor, Eperjesi János adatközlők alapján. 


\section{Németlukafa helyzetének alakulása az üveghuta és a cserépedény manufaktúra megszűnése után, 2010-ig}

Az 1973. évi Helységnévtár Lukafapuszta néven említi, lakóinak számát 56-ban adja meg. „Baranya megye Térképe" című, 1:150.000-hez léptékű térképlap (Cartographia, 1993. Bp.) még két Lukafát tűntet fel a színhelyen. Az északibbnak (amit az itt lakók „Lukafa a falu" néven emlegetnek), Németlukafapuszta nevet ad. Az ettől kb.1 km-re délre fekvő települést Lukafapuszta névvel illeti. A régi okmányok, anyakönyvek az északabbra fekvő Németlukafát egyszerüen Lukafának, ritkán Németlukafának nevezik, a délre fekvőt rendszeresen Pust Lukafa, Lukafapuszta néven emlegetik. ${ }^{104}$ A századfordulón a Biedermann-féle uradalom részeként kb.1919-ig (a környékbeli lakosság emlékezetében is) Deszkametsző a neve. ${ }^{105}$

Az egymáshoz közeli két Lukafa település, a "falu” és a „puszta” között szerkezeti különbség is volt. A vitráriusok által lakott „falu” házai a gyár jobboldalán a vidék más apró falvaihoz hasonlóan „fésűs rendszerü" utcasort alkottak. Minden házhoz kert, ól és istálló tartozott. (Az ipari munkásnak számító vitráriusok egyben saját ellátásukra tehenet, sertést és baromfit is tarthattak, zöldséget termeltek.) Ettől az 1 km-re fekvő puszta szórt szerkezete uradalmi istállókkal, aklokkal, cselédházakkal, termelési eszközökkel, teljesen eltért. A vitráriusok, hamuzsírfőzők és „porcellánosok”, mint szabad emberek a vezetőkkel együtt, minden időben kizárólag a „faluban” laktak, a pusztán nem. A pusztán szolgának számító, szegődményes kocsisok, béresek, pásztorok, későbben uradalmi cselédnek nevezett magyar családok éltek. Az üveggyári munkások a pusztai béreseket lenézték, a huta bezárása után egy ideig ott maradt felnőttek sem szegődtek be soha béresnek, azaz uradalmi cselédnek, csupán napszámos munkát és részes aratást vállaltak. ${ }^{106}$ Horváth J. Gyula feltételezése szerint a favágó cigányok is a pusztán laktak volna. A helyiek emlékezete szerint a cigányokat a pusztaiak sem fogadták maguk közé, azok fából, sárból tákolt kunyhóikban mindig a kitermelt erdőrész szélében ütöttek tanyát. A hamuégetők, hamuzsírfőzők és szénégetők - az éjjel-nappali folyamatos munkatevékenység miatt - ugyancsak a munkahelyük színterében, a kitermelt erdőrész közelében ideiglenesen (fából, tapasztott sárból) épült, igénytelen lakásokban éltek. ${ }^{107} \mathrm{~A}$ cserépgyár és az üveggyár megszűnése (1888) után az ipari munkásság nagyrésze elvándorol, a terület majorsági föld lesz, a Biedermannok uradalmi rendszerben müvelik tovább. Az üzemi épületeket lebontják, a vitráriusok felszabaduló házaiba magyar nyelvű erdészeket, vincellért, téglást és cselédeket költöztetnek. 1890 után Németlukafa, Lukafa-pusztával (Deszkametszővel) együtt a Biedermannok szentmárton-pusztai gazdaságának lesz része, amely össszesen 40 szegődött (konvenciós) cselédet alkalmaz. ${ }^{108} \mathrm{~A}$ területen bécsi és ber-

104 H. J. Gy. Kéziratrészleg, 49-50. p.

105 Raichl Sándor és Eperjessy Ernő adatai.

106 Raichl Sándor információi és Eperjessy E. adatai.-

107 Ua. Raichl Sándor és Eperjessy E.

108 Szentmárton-puszta, mint Biedermann uradalmi központ, nem azonos a töle keletre lévő Gödreszentmárton községgel. Szentmártonpuszta Almamellék közigazgatási területének része. lini tőke bevonásával, az eddigi ipari jellegtől teljesen eltérő, új, nagyméretü agrárfejlesztésre kerül sor. ${ }^{109}$

(Ezidőben Németlukafa-pusztán - a volt faluban és a pusztán, valamint Sasréttel együtt - élő családok: 1 főerdész, 1 alerdész, 1 vadász, 2 erdész, 1 tanító, 1 segédtiszt, 1 vincellér, 1 mindenes (udvaros), 8 kocsis, 2 négyökrös béres, 1 számadó (ellető)kanász, 4 uradalmi kanászbojtár, 1 uradalmi gulyás, 1 cselédcsordás, 1 cselédkanász, 1 szerződött téglás, (egy időben 1 csikós és 1 juhász is). ${ }^{110}$

Többek közt a kb. 4000 holdas erdőgazdaság irányítását leválasztják az uradalmak (Szentmárton, Korcsány, Németlukafa, Terecseny) termelésétől. Bassler Ernő, az erdőgazdaság képzett vezetője a monarchia fejlett erdőgazdálkodásainak mintájára szervezi meg a fa- és vadgazdálkodást Sasrét központtal. 1900 körül Sasréten kétszintes vadászkastély épül. ${ }^{111} 1906$-ban Szentmártonpuszta, Lukafa, Terecseny, Sasrét puszták cselédgyerekei számára elkészül az egytantermes elemi iskola, amelyet az uradalom tart fenn. 1910 után a különböző gazdasági egységeket lóhúzta iparvágány (kisvasút) köti össze a 8 km-re lévő almamelléki MÁV vasútállomással, amely a gazdaság és az erdészet nagytételü termékeinek a vasúti szállítását könnyítette meg. ${ }^{112} \mathrm{~A}$ századfordulón 60 hold szőlőt telepítenek, 1904-1905-ben hozzá 3 szintes, folyóvízzel ellátott hatalmas pincészetet építenek, korszerü gépesített berendezéssel, gabonaőrlővel, $80 \mathrm{~m}$ hosszú pincével, stb. (Legfelső szintje magtár, közép- és alsó szintje sertésnevelő, alul pincészet.) ${ }^{113}$ Közelében a határ legmagasabb pontján a bárói család kétszintes, üveges tüdőpavilonnal (szanatóriummal) is kísérletezett, ami eredeti célja szerint sohasem üzemelt. 1920-21-ben a vizenyős szentmártoni völgyben 62 holdon $9 \mathrm{db}$. jól jövedelmező halastavat hoznak létre. A XX. század első felében virágzó uradalom fő jövedelmi forrása a gabonafélék, kukorica, borsó és magfélék (lucerna-, lóhermag) termeléséből és állattenyésztésből

109 Ua. Raichl S. és Eperjessy E.

110 Ua. Raichl S. és Eperjessy E. (Németlukafán a Biedermannok uradalmában az emlékezet szerint 1900-1945 között megfordult alkalmazottak és cselédek: a) Bassler Ernő főerdész, Baracs (Bassler) Alfréd föerdész, Varga Antal alerdész, Tóth János erdész, Magyar ... erdős, Boder(Bodor) József erdész, Frigyes József erdész, Tomolák Pál erdész, Andics Ferenc erdőőr; Raichl Sándorné Bassler Gertrud tanítónő; b) Szerződött alkalmazottak: Nyaka György vincellér, Bodrog Ferenc vincellér, Marosics József ács, Eisner György kovács, Hárs János bognár, Domiján Józse téglás, Serdán János téglavető, Varga Simon szénégető; c) Uradalmi, másszóval szegődött cselédek (kocsisok, béresek, pásztorok) 1934-ben: Papp János gazda, Fodor István urasági kanász, Fodor Ferenc béres, Guzmics Ferenc urasági kanász, Németh István gulyás, Németh Ferenc kocsis,Oreczki János béres, Horváth István cselédkanász,Szárszó István kocsis, Papp Imre, Pető János kocsis, Skrinyár Lajos, Tankovics Péter kocsis, Tankovics János kocsis, Gál Márton béres, Lehőcz Károly béres, Eperjesi Imre mindenes, Fodor János kocsis; d) Előforduló cselédnevek még: Tinusz József, Szijártó József, Dancs István, Nyári István, Nagy József, Zsebi József, Kovács István és József, Bozsovics György és József, Vajda Imre, Lakatos Ferenc, Lukács István, Szercsik János, Strasszer, Kirsch András, Hencz, Jusics Mihály, Andics József és István, stb.

111 Ua. Raichl S. és Eperjessy E.

112 Az összes kisvasút hossza (az erdőkitermeléstől függően) 10-12 $\mathrm{km}$ is lehetett. Adatközlö: Eperjessy $E$.

113 A nagytételü bort a pécsi Littke-pezsgőgyár részére termelték. Adatközlö: Raichl Sándor, 1969. 
(sertés, szarvasmarha, ló,juh) származott. ${ }^{114}$ 1932-ben Németlukafa lakóinak száma Deszkametsző és Sasrét pusztákkal együtt: 81 magyar, 1 német, 3 cigány. ${ }^{115}$ A század elején cséplőgép, az 1920-as években több gőzgép került az uradalomba, 1934 körül beszerelik a telefont, stb. ${ }^{116}$ Mindebböl kitünik, hogy a hajdani üveghuta és vidéke mint uradalom, a XX. sz. első felében éli fénykorát.

Az 1945-ös földreform idején az uradalom lukafai részét nem parcellázzák fel, hanem állami gazdaság formában termel tovább. Felújítják a szölészetet, az 1950-es években villamosítják, bolti bevásárló helyet létesítenek, korszerüsítik a kisvasútat, Sasréten modern fürésztelepet működtetnek. 1960-as évektől szilárd bekötőút köti össze a Szigetvár-Kaposvár közti országúttal, a régi „üveggyári” házak mellett és Sasréten új, korszerű erdészlakásokat építenek. Ennek ellenére a mezőgazdasági dolgozók (többsége volt cseléd), egyre nagyobb számban hagyják el a települést és költöznek egykori cselédtársaik mellé a szomszédos (Almamellék, Szentlászló, Boldogasszonyfa, stb.) falvakba. ${ }^{117}$

Németlukafáról, a „faluból” (a volt üveggyár területéről) 1975-ben Hauser Mátyás erdész és családja, ${ }^{118}$ majd (érdekes sorsfordulatként) utolsónak Aschenbrenner Jenő nevű vadász költözött el 1977ben, mégpedig Hamuházára. ${ }^{119}$ A következő években nemcsak a még fennmaradt egykori üvegfuvó házakat, hanem a korszerű (fürdőszobás) erdészlakásokat is lebontják. Ezidőtájt átmenetileg a pusztai cseléldlakásokban még néhány cigánycsalád él. 1982-

114 Adatközlö Raichl Sándor, 1969 és Eperjessy E.

115 Magyar Statisztikai Közlemények.1932. 83.köt. 271.p. Bp. 116 Ua. Raichl S.

117 Eperjessy E. feljegyzéseiböl

118 Adatközlő: Hauser Mátyásné Frigyesi llona, Ibafa,2011.

119 Könyves Kálmán (Szigetvár) volt erdészeti vezető és Tihanyi Attila fövadász (Sasrét) szíves közlése, 2012. ben ezek bontását is megkezdik. ${ }^{120} 2001$-ben már csak az uradalmi nagyistálló, illetve kiemelkedő helyen az egykori háromszintes szőlészeti épület uralja a tájat üresen. A németlukafai völgyet a teljes elnéptelendés után 2010-re visszafoglalta az erdő. ${ }^{121}$

Jelenleg a Sasréti Erdőgazdaság maradt kultúrtájnak, ahol a Mecseki Erdőgazdaság részeként Szigetvár központtal tervszerü erdő- és vadgazdálkodás folyik. A kellemes völgyben álló kastélyt nagypénzű vadászok keresik fel. Az iskola épületében ugynevezett erdei iskolaként turista csoportokat fogadnak, a motorizált „erdei kisvasúton” hétvégeken számos kiránduló érkezik. Sasréten 2010-ben állandó jelleggel mindöszsze 3-4 erdész család élt.

\section{Köszönetnyilvánítás}

Ezúttal mondok köszönetet a tanulmány megjelentetéséhez segítséget nyújtó Szerveiné Miholcsai Máriának, Sebestyén Ferencnek, Ráczné Gádor Gyöngyvérnek, Hauserné Frigyesi llonának, Tihanyi Attilának, Sajgó Ferencnek, Könyves Kálmánnak, Raichl Sándornak, Bánki Lászlónak.

120 Adatközlő: Tihanyi Attila fővadász, Sasrét, és Könyves Kálmán volt erdészeti vezetö, 2012. - Az egykori cselédlakásokba az 1970-es években átmenetileg terecsenyi beás-cigányok költöznek. 1982ben ezek bontását is megkezdik. Utolsó lakóját, a cigány Rozi nénit 1990-ben költöztetik át Irma-pusztára.

121 Tihanyi Attila szíves közlése és Eperjessy E. feljegyzései alapján. - Tihanyi Attila információja: A háromszintes uradalmi pincészetet az erdészet tetőcserével igyekszik megmenteni, az uradalmi istálló romos épületének 2012-ben tervezett bontásával Németlukafapusztán az utolsó építmény is eltünik.

\section{Irodalom}

CSIFFÁRY G. 2006: Magyarország üvegipara 1920-ig. - Eger

EperJessy E. 2006: Puszták népe a Zselicben (1900-1950). - Budapest.

FÉNYES E. 1851: Magyarország gheographiai szótára. - Pest.

HORVÁTH J. Gy. 1973: Székely szállások az Almás patak forrásvidékén. - Zselici Dolgozatok II: 109-138. Pécs.

HoRvÁTH J. GY. 1976: Adatok a zselici vizimolnárok történetéhez. - Zselici Dolgozatok III: 98-101. Pécs.

HoRvÁTH J. Gy. 1976: Baranya és Tolna megye által kibocsátott oklevélmásolat a pécsi püspök és székeskáptalan részére. - Zselici Dolgozatok III: 121-123. Pécs.

HORVÁTH J. GY. 1979: II. Ferenc 1796-ban kelt adománylevele, amelyben Boldogasszonyfa, Keményfa és Szentmargita helységeket Igmándy Sándornak adományozza. - Zselici Dolgozatok IV: 113115. Pécs.

KIRÁLY L. 1976: Ipartörténeti emlékek Somogy megye földrajzi neveiben. - Kutatások a gazdasági és társadalmi élet szolgálatában. DélDunántúli Konferenciák, Szekszárd 1975: 156-163.
L. IMRE M. 1977: Adatok a mecseknádasd-óbányai fazekassághoz. I. Janus Pannonius Múzeum Évkönyve 20-21: 183-196.

LANG Á. 2008: Üveghuták a Kelet-Mecsekben. - Pécs.

LeHmann A. 1969: XIX. századi üveghuták a Zselicben. - Baranyai Müvelödés, 1969 június: 94-96. Pécs.

LeHmAnN A. 1971: Adatok a szentlukai üveghutáról (1807-1808). - Somogy Megye Múltjából 2: 109-136. Kaposvár

LEHMANN A. 1971: Adatok a Zselic üvegfúvó üzemeinek történetéből. Zselici Dolgozatok I.: 59-61. Kaposvár.

MÉREY Gy. 1951: Magyar iparfejlődés 1790-1848. - Budapest.

KIRÁLY L. ÉS VÁRKONYI I. (szerk) 1974: Somogy megye földrajzi nevei. Budapest.

TELKES S. 1895: Üvegiparunk. - Budapest.

VARGHA K. 1941: A délkeleti Zselic: Tájföldrajzi, településtörténeti és magyar-német összehasonlító népzene kutatási adatok. - Kaposvár

VARGA V. 1989: Régi magyar üveg. - Budapest.

VERES L. : Üvegmüvességünk a XVI-XIX. században. 


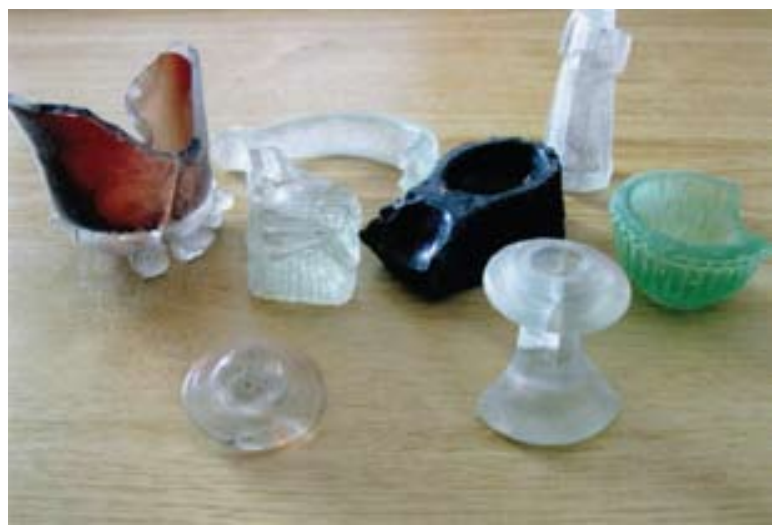

1. ábra. Üvegtöredékek a németlukafai üveggyár termékeiből. Hauserné Frigyesi llona gyüjteményéből. Fotó: Hauserné Frigyesi Ilona, Ibafa, 2010.

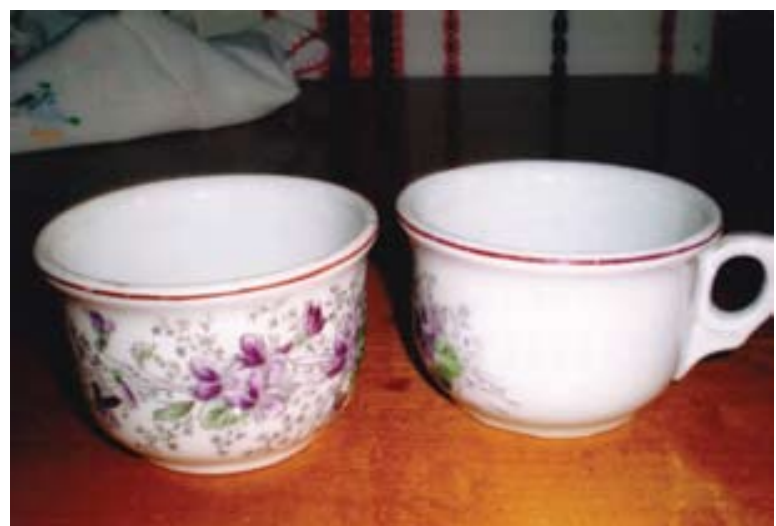

2. ábra. Páros díszcsésze. Emlékezés szerint a németlukafai cserépedénygyár terméke. Származási hely: Almamellék, 1946. Eperjessy János tulajdonában. Fotó: Eperjessy Ernő, 1996.

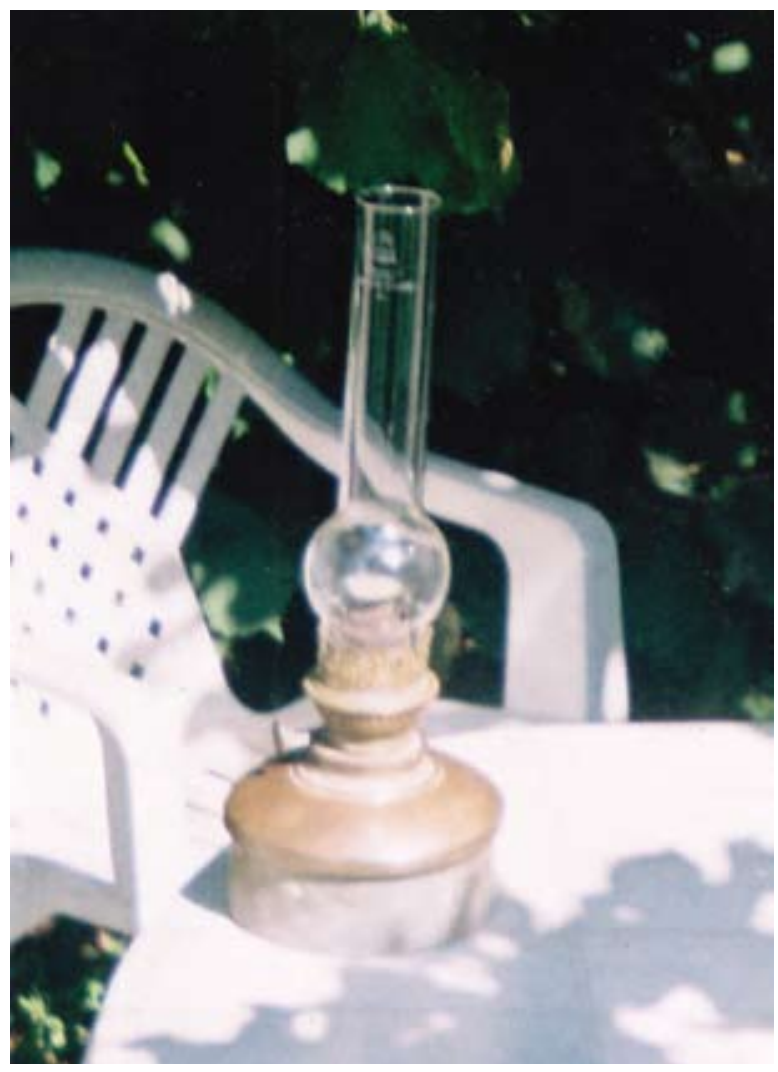

3. ábra. 15-ös petróleumlámpa „Lukafai üveggyár lerakata, Pécs” cégjelzéssel. Hauserné Frigyesi llona tulajdonában, Ibafa. Fotó: Hauserné, Frigyesi Ilona, Ibafa, 2010.

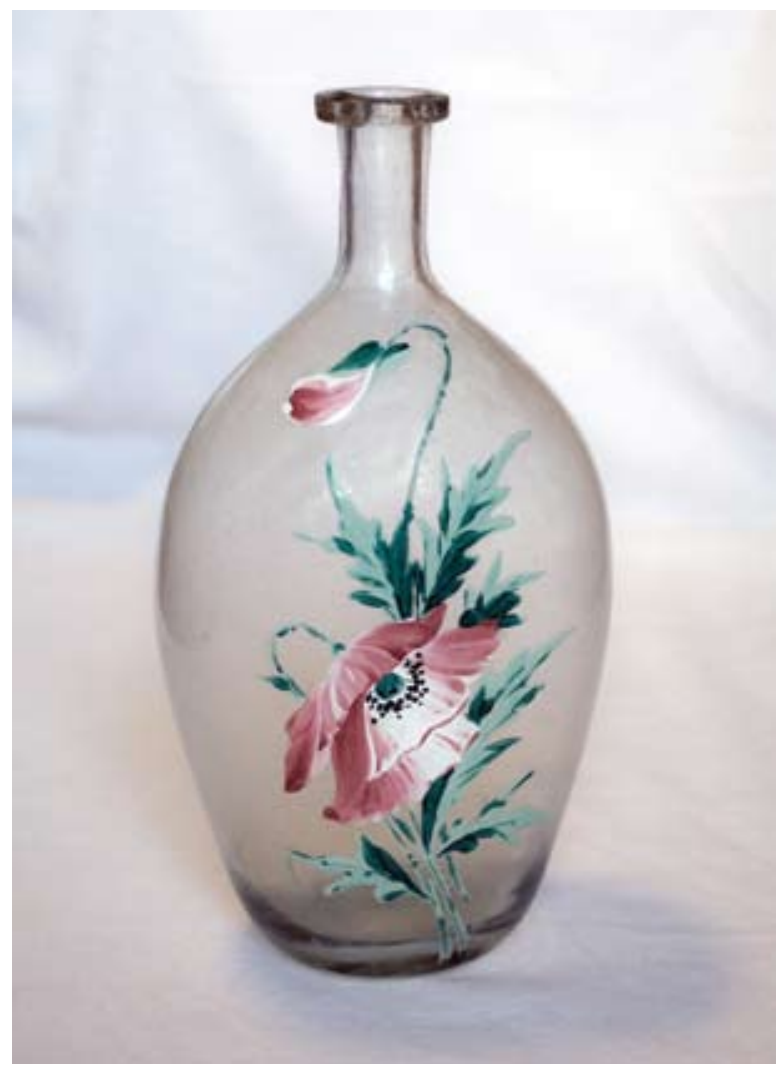

4. ábra. Üvegváza. $25 \mathrm{~cm}$ magas, átlátszó fehér fúvott üveg, müvészi olajfestés díszítéssel. Emlékezés szerint a németlukafai üveghuta terméke, készült 18701880 körül. Dr.Baracs Endre tulajdonában (Pécs). Fotó: Baracs Dénes, 2012. 


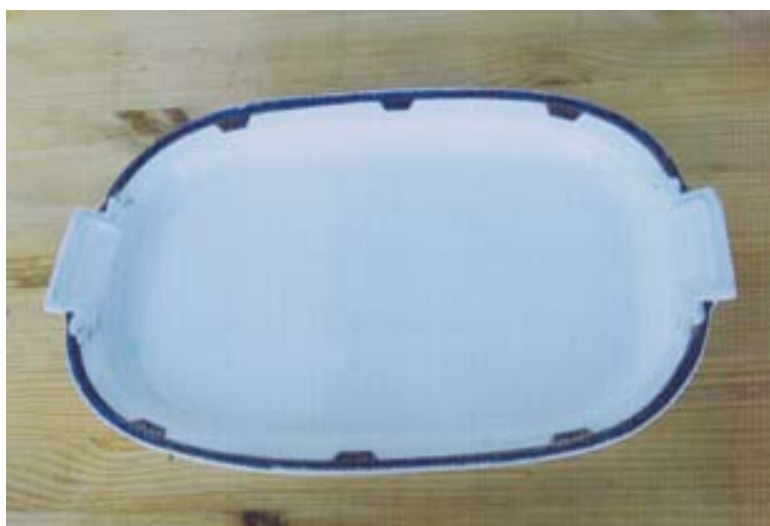

5. ábra. Pecsenyéstál kobaltkék széllel és aranyozással. Alján: „Lukafai üveggyári raktár, Pécsett” cégjelzéssel. A németlukafai cserépedénygyár terméke, 1850 körül. Ráczné Gádor Gyöngyvér tulajdonában,

Mike. Fotó: Ráczné Gádor Gyöngyvér, 2010.

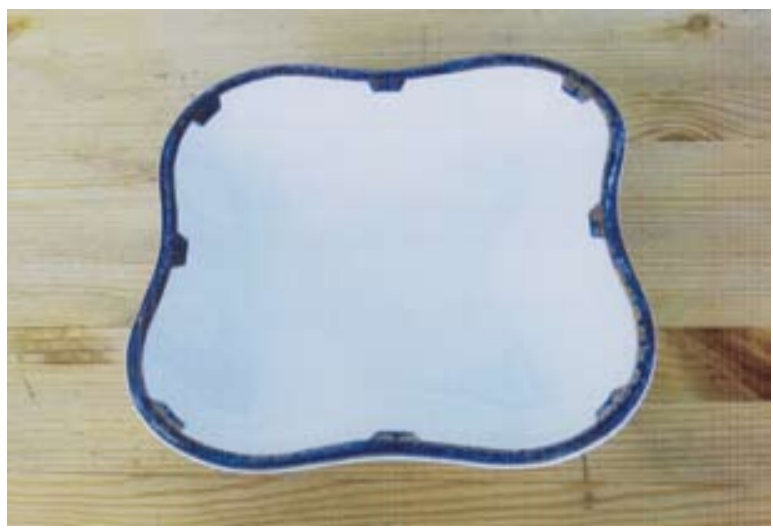

7. ábra. Salátástál, kobaltkék széllel, aranyozással. Alján „Lukafai üveggyári raktár, Pécsett” cégjelzéssel. Készült a németlukafai cserépedénygyárban, 1850 körül. Ráczné Gádor Gyöngyvér tulajdonában, Mike. Fotó: Ráczné Gádor Gyöngyvér, 2010.

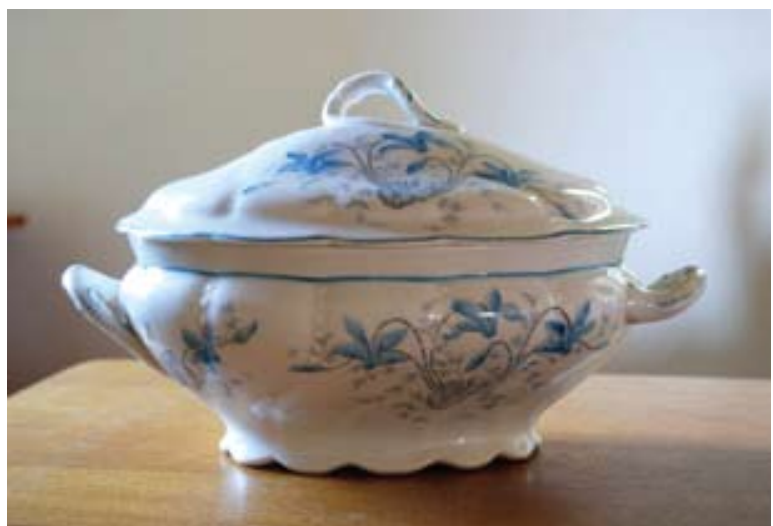

9. ábra. Barokk levesestál, a németlukafai keménycserépedény üzem terméke, 1870-1880 körüli időböl.

Ráczné Gádor Gyöngyvér tulajdonában, Mike. Fotó: R. Gádor Gyöngyvér, 2012.

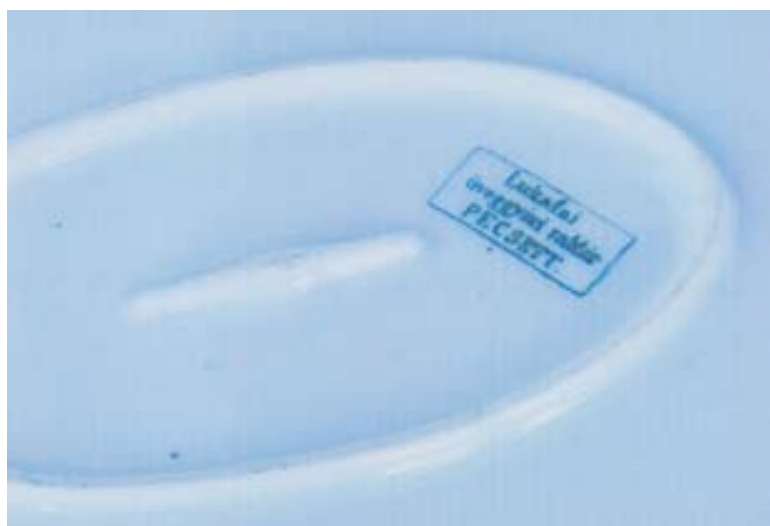

6. ábra. Pecsenyéstál alja „Lukafai üveggyári raktár” cégjelzéssel. Készült a németlukafai cserépedénygyárban 1850 körül.

Ráczné Gádor Gyöngyvér tulajdonában, Mike. Fotó: Ráczné Gádor Gyöngyvér, 2010.

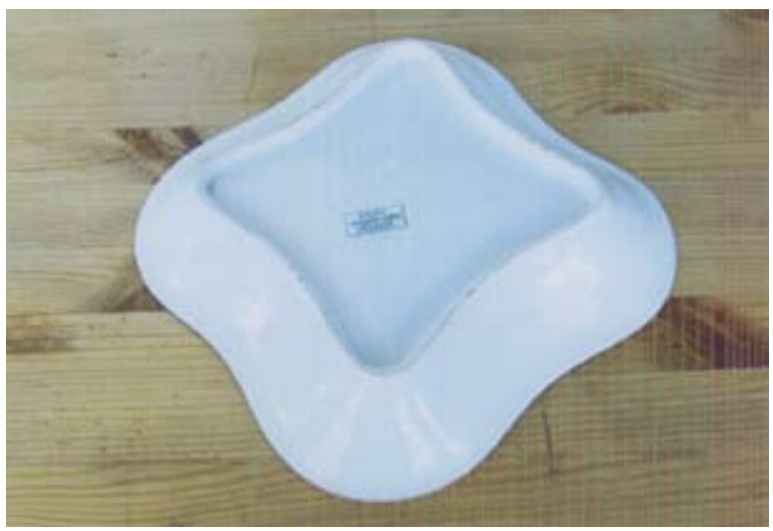

8. ábra. Salátástál alja „Lukafai üveggyári raktár, Pécsett” cégjelzéssel. Készült a németlukafai cserépedénygyárban, 1850 körül. Ráczné Gádor Gyöngyvér tulajdonában, Mike.

Fotó: Ráczné Gádor Gyöngyvér, 2010.

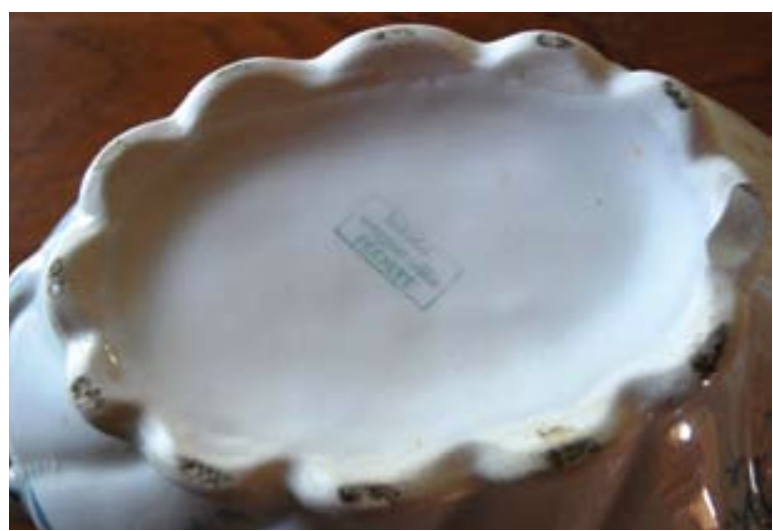

10. ábra. Barokk levesestál alja „Lukafai üveggyári raktár, Pécsett" cégjelzéssel.

Fotó: Ráczné Gádor Gyöngyvér, Mike. 2012. 


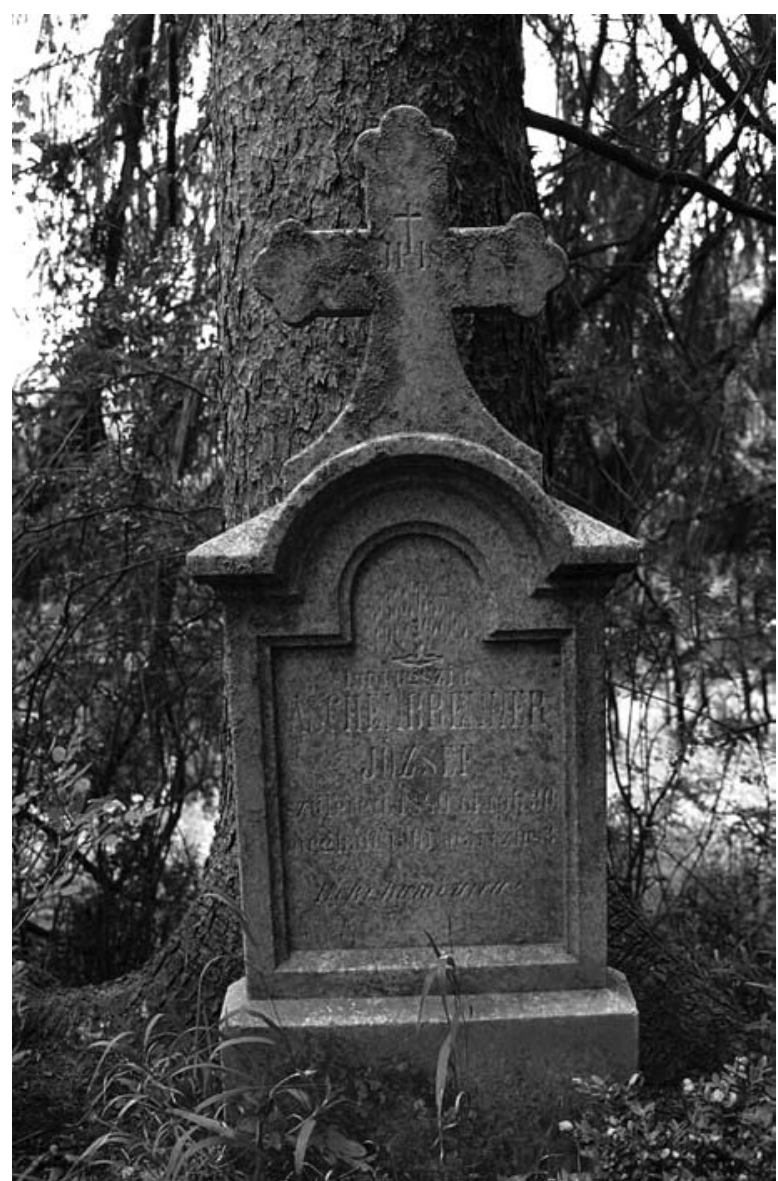

11. ábra. Németlukafai temető. Az egykori manufaktúra egyik vezetőjének sírköve. Felirat: „Itt nyugszik Aschenbrenner József. Született 1849 október 30. Meghalt 1910 augusztus 8. Béke poraira." Fotó: Tihanyi Attila, 2012.

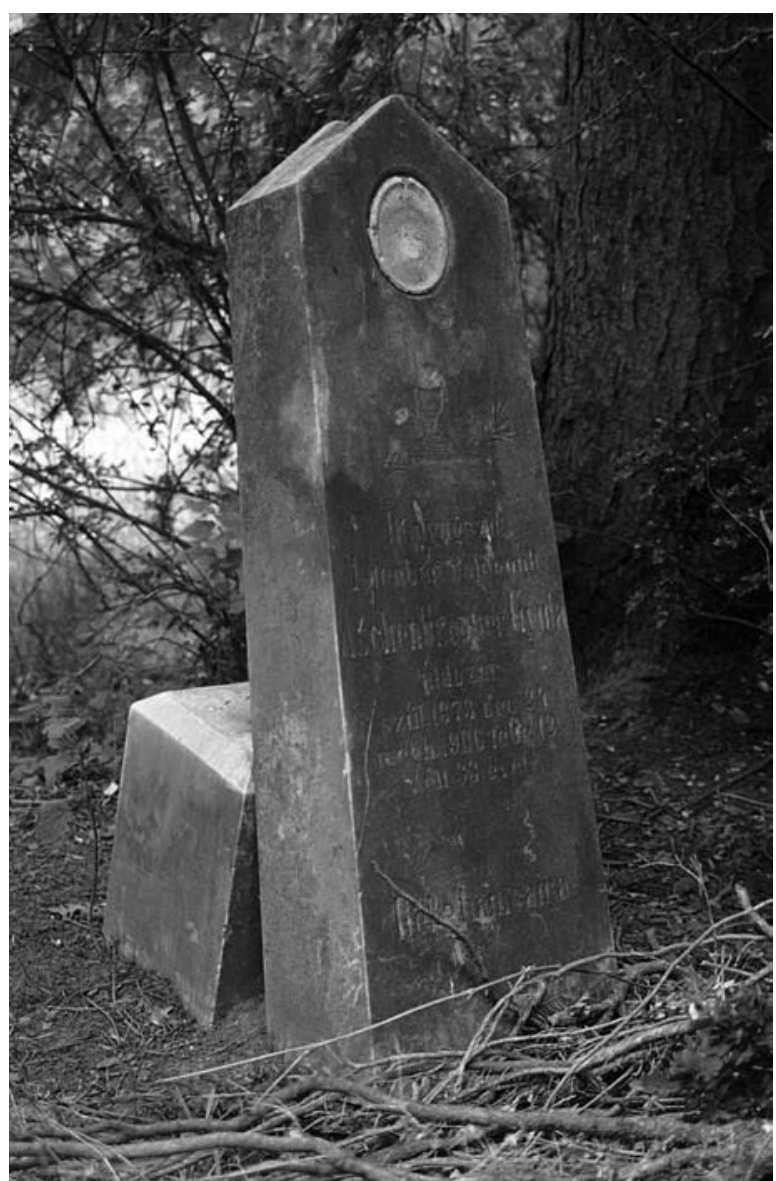

12. ábra. Németlukafa, temetői sírkő az „üveggyáriak" sorában. Felirata: „Itt nyugszik Istenben boldogult Aschenbrenner Gyula áldozár (rk.pap). Szül. 1873. dec. 24. Megh. 1906. február 18. Élt 33 évet. Béke hamvaira." (Régebben a sírkövön porcelán arckép volt.) Fotó: Sebestyén Ferenc, 2001.

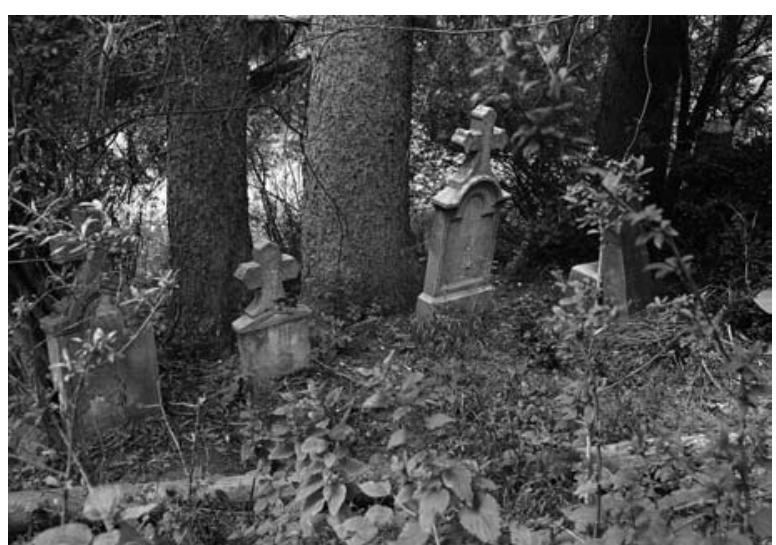

13. ábra. Németlukafa, temetőrészlet az egykori „üvegesek” és „porcelánosok” sírköveivel. Fotó: Tihanyi Attila, 2012.

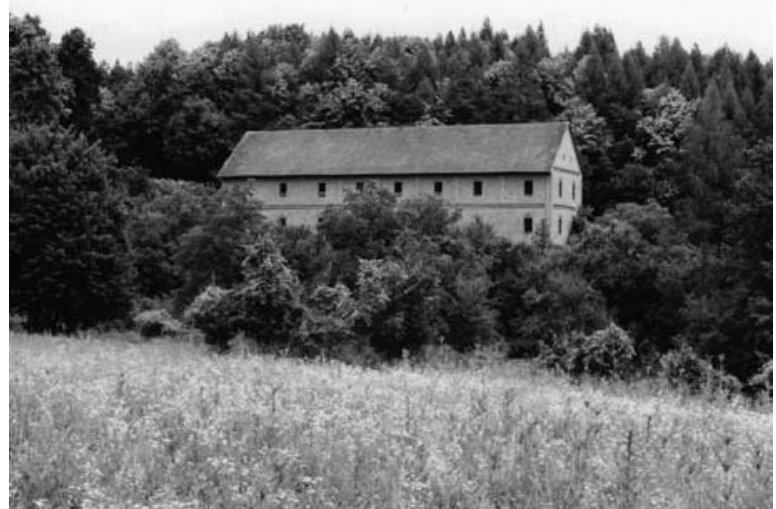

14. ábra. Németlukafa, a Biedermann-uradalom utolsó hírmondója, az erdővel benőtt volt magtár és borpincészet (épült 1904-1905-ben). Fotó: Sebestyén Ferenc, 2001. 


\title{
Supplementary data for the history of the glasshouse of Németlukafa
}

\author{
J. GYULA HORVÁTH \& ERNÖ EPERJESSY
}

In the 18th and 19th century at least 6 glasshouses were proven to exist in the forests of Zselic (in Somogy and Baranya counties). The founders of these were the local landlords (Festetics, Batthyány, Czindery etc.). The glasshouses were usually profitable for 20-30 years. The glassworkers were free industrial workers. The skilled workers were mainly Catholics from the German Sudetes mountains. The raw material used in the glass manufactures was potash, produced in the asheries by the so-called "ash-villains” or „ash-scamps" in the cleared wooded areas.

The most significant glasshouse was in operation between 1799 and 1888 in Németlukafa, side by side with faience manufacture (1840-1860). The raw material and the finished products were transported by Jewish traders. The Spitzer and Wohlheim firm has even opened a splendid china shop in Pécs called "the storage of the Lukafa glass factory". In the 1850's the equipment of the faience manufacture was purchased by the Zsolnay-family to start the first production of the famous ceramic factory

The glass manufacturing and the ashery in the forest came to an end partially because of the more rational sylviculture and the more organized manorial agriculture. The glass workers moved to Ajka, Slavonia and to the neighbouring German villages and became hired in the manors as servants.

The manorial agriculture flourished in the first half of the 20th century. By the end of the 20th century Németlukafa became completely unpopulated and by 2010 the glasshouses and the faience factory were overgrown by forests. 